OPEN ACCESS

Edited by:

Hongbin Liu,

Hong Kong University of Science and Technology, Hong Kong

Reviewed by:

Nils Risgaard-Petersen,

Aarhus University, Denmark

Gwenael Piganeau,

UMS2348 Observatoire

Océanologique de Banyuls-sur-Mer

(OOB), France

*Correspondence:

Ulrich Sommer

usommer@geomar.de

Maria Moustaka-Goun

mmustaka@bio.auth.gr

Specialty section:

This article was submitted to

Aquatic Microbiology,

a section of the journal

Frontiers in Microbiology

Received: 17 April 2018 Accepted: 24 September 2018

Published: 09 October 2018

Citation:

Stefanidou N, Genitsaris S, Lopez-Bautista J, Sommer U and Moustaka-Gouni M (2018) Unicellular Eukaryotic Community Response to Temperature and Salinity Variation

in Mesocosm Experiments.

Front. Microbiol. 9:2444.

doi: 10.3389/fmich.2018.02444

\section{Unicellular Eukaryotic Community Response to Temperature and Salinity Variation in Mesocosm Experiments}

\author{
Natassa Stefanidou", Savvas Genitsaris ${ }^{1,2}$, Juan Lopez-Bautista ${ }^{3}$, Ulrich Sommer ${ }^{4 *}$ and \\ Maria Moustaka-Gouni ${ }^{1 *}$
}

\begin{abstract}
${ }^{1}$ Department of Botany, School of Biology, Aristotle University of Thessaloniki, Thessaloniki, Greece, ${ }^{2}$ School of Economics, Business Administration and Legal Studies, International Hellenic University, Thermi, Greece, ${ }^{3}$ Department of Biological Sciences, The University of Alabama, Tuscaloosa, AL, United States, ${ }^{4}$ Geomar Helmholtz Centre for Ocean Research Kiel, Kiel, Germany
\end{abstract}

Climate change has profound impacts on marine biodiversity and biodiversity changes in turn might affect the community sensitivity to impacts of abiotic changes. We used mesocosm experiments and Next Generation Sequencing to study the response of the natural Baltic and Mediterranean unicellular eukaryotic plankton communities (control and $+6^{\circ} \mathrm{C}$ heat shock) to subsequent salinity changes ( $-5 \mathrm{psu},+5 \mathrm{psu}$ ). The impact on Operational Taxonomic Unit (OTU) richness, taxonomic and functional composition and rRNA:rDNA ratios were examined. Our results showed that heat shock leads to lower OTU richness (21\% fewer OTUs in the Baltic and 14\% fewer in the Mediterranean) and a shift in composition toward pico- and nanophytoplankton and heterotrophic related OTUs. Heat shock also leads to increased rRNA:rDNA ratios for pico- and micrograzers. Less than $18 \%$ of shared OTUs were found among the different salinities indicating the crucial role of salinity in shaping communities. The response of rRNA:rDNA ratios varied highly after salinity changes. In both experiments the diversity decrease brought about by heat shock influenced the sensitivity to salinity changes. The heat shock either decreased or increased the sensitivity of the remaining community, depending on whether it removed the more salinity-sensitive or the salinity-tolerant taxa.

Keywords: coastal marine plankton, climate change, Illumina sequencing, 18S rRNA gene, cDNA, RNA/DNA ratio

\section{INTRODUCTION}

Multiple components of climate change are projected to affect all levels of biodiversity and thus ecosystems structure and resilience (Bellard et al., 2012). Based on current knowledge (Intergovernmental Panel on Climate Change [IPCC], 2014), sea surface temperature is predicted to increase up to $3-5^{\circ} \mathrm{C}$ by the year 2100 with even stronger increases in semi-enclosed coastal seas. In addition to increase mean temperature extreme events, such as heat waves, are expected to increase in frequency and strength. Altered regimes of ice-melt, evaporation and precipitation regimes will change salinity (Harley et al., 2006), with a moderate increase of salinity globally by $0.5 \mathrm{psu}$, but much stronger changes regionally. For the western Baltic Sea, one of our study sites, Andersson et al. (2015) predict a decrease of 2-3 psu during summer season as an ensemble average 
of several models, while some individual models predict even stronger decreases (Meier et al., 2006). For Thermaikos Bay, Krestenitis et al. (2012) found a salinity decrease of almost 1 psu for the period 1994-2007 with a continuous trend. Physical changes like these will lead to changes in community composition, biodiversity and functional attributes which in turn will influence the responsiveness of communities to further physical changes, as has been conceptualized by the doublestressor concept of Vinebrooke et al. (2004). So far the impact of different aspects of climate change on plankton communities has been studied quite extensively (e.g., Yvon-Durocher et al., 2015; Kaur-Kahlon et al., 2016; Moustaka-Gouni et al., 2016), while the effect of plankton community changes on the sensitivity to environmental pressures has not been the focus of experimental studies.

The use of experimental mesocosms is a well-established tool to explore microbial community responses to environmental changes with the advantage of manipulation, high replication and free factorial combination of stress factors (Benton et al., 2007). Until recently, the majority of investigations that studied the impacts of climate change on microeukaryotic planktic community composition were based on morphological species determination by microscopy. This provides a sufficient resolution in taxa rich in distinctive morphological features (e.g., diatoms, thecate dinoflagellates) while it might underestimate actual biodiversity in taxa poor in distinctive morphological features (e.g., naked flagellates) and miss rare, small, and cryptic or endosymbiotic species (Medinger et al., 2010; Behnke et al., 2011; Christaki et al., 2014). Investigations of the $18 \mathrm{~S}$ rRNA gene (rDNA herein) diversity often reveal long lists of previously undiscovered taxa of unicellular eukaryotes (Bik et al., 2012). Next Generation Sequencing (NGS) provides a comprehensive tool for investigations of marine microeukaryotic community structure and has recently revealed previously hidden biodiversity (de Vargas et al., 2015). The majority of mesocosm experiments using NGS studied the impacts of climate change on bacterial communities via $16 \mathrm{~S}$ rDNA sequencing (Muscarella et al., 2014; Baltar et al., 2016; Guo et al., 2016) and only few examined planktic microeukaryotic assemblages (Belkin et al., 2015; Moustaka-Gouni et al., 2016).

While sequencing of rDNA allows detecting the majority of microbe biodiversity regardless of their viability and inferred activity, estimating microbial activities is fundamental to understand the functioning of ecosystems. Generally the quantity of rRNA is proportional to both the number of ribosomes and total RNA concentration (Poulsen et al., 1993), therefore it can be used as an indicator of cell activity. In recent years, the advance of NGS tools has allowed the combination of rDNA sequencing along with rRNA sequencing (RNA-seq, by means of cDNA sequencing) as a way to distinguish organisms with strong indication of high ribosomal activity (henceforth active) from those with low/no ribosomal activity (henceforth non-active) (Campbell et al., 2011; Massana et al., 2015; Hu S.K. et al., 2016). Thus, the ratio of rRNA sequences to rDNA sequences (rRNA:rDNA) has been used as a proxy of metabolic activity (Logares et al., 2015; Hu S.K. et al.,
2016). This application has revealed a significant portion of rare species with high activity (Campbell et al., 2011; Hu S.K. et al., 2016) that could act as a genetic reservoir and respond rapidly to environmental changes (Logares et al., 2015).

In mesocosm experiments, phylogenetic markers have been used with classical molecular tools in order to identify environmental variability effects on bacterial (e.g., Lebaron et al., 1999; van der Zaan et al., 2010; Newbold et al., 2012) archaeal (e.g., Bowen et al., 2013), and protistan (e.g., Countway et al., 2005) communities. Here we chose to apply, for the first time in a mesocosm experiment, $18 \mathrm{~S}$ rDNA sequencing together with $18 \mathrm{~S}$ rRNA high throughput sequencing to study the impacts of heat shock and changing salinity on composition and inferred activity of two natural microeukaryotic planktic communities. The two study sites were Kiel Bight in Baltic Sea and Thermaikos Bay in Mediterranean Sea. Kiel Bight is a shallow ending of the Baltic Sea experiencing a wide range of salinity throughout the year. It is a eutrophic marine ecosystem where phytoplankton biomass has been doubled the last century (Wasmund et al., 2008). In the North-Eastern Mediterranean, Thermaikos Bay is the innermost part of Thermaikos Gulf, which is a eutrophic coastal area (Simboura et al., 2016) with marked diatom and dinoflagellate blooms (Nikolaides and Moustaka-Gouni, 1990; Mihalatou and Moustaka-Gouni, 2002).

Following Vinebrooke's et al. (2004) double stressor concept we performed two mesocosm experiments, in which a transient "pulse" stressor should change plankton composition and biodiversity and thus affect the resistance to a subsequent "press" stressor of different nature. For the "pulse" stressor we chose a temperature increase mimicking natural heat-waves, while a positive and negative change in salinity were chosen as subsequent, second stressor.

Our experiments were primarily designed as "proof-ofprinciple" experiments testing Vinebooke's double stressor concept. However, we also aimed to put the nature and magnitude of the stressors applied into the context of Global Change research, because the double stressor concept is particularly important in that context, if biodiversity losses driven by one Global Change related factor (e.g., temperature) weaken the resistance of ecological communities against further stressors. The magnitude of temperature change $\left(6^{\circ} \mathrm{C}\right)$ employed in our study is clearly below the annual temperature amplitude of midlatitudes, but conforms to the more pessimistic Global Change scenarios for mean temperature changes in coastal seas and to short term temperature changes during heat-waves which are expected to increase in frequency and magnitude with ongoing climate warming (Intergovernmental Panel on Climate Change [IPCC], 2014). In terms of their temporal scale, the experiments mimick, how a change in the species inventory driven by a heat wave would influence the ability of the resultant phytoplankton communities to cope with salinity changes. The magnitude of salinity changes was within the range of short-term moving of oceanographic fronts of coastal seas and within the predicted range for long-term changes in coastal seas (Meier et al., 2006; Andersson et al., 2015). 
Our working hypotheses were:

(1) The heat shock and salinity changes will lead to composition shifts and biodiversity changes of unicellular eukaryotic communities

(2) The heat shock and salinity changes will affect rRNA/rDNA ratios of unicellular eukaryotic communities

(3) The heat shocked communities will have lower resistance to salinity changes

\section{MATERIALS AND METHODS}

\section{Experimental Design}

We performed a two-step experiment. In the first step, experimental plankton communities $(10 \mathrm{~L}$ each) were subjected to two different temperatures (A: control, i.e., ambient temperature of the study site, $\mathrm{H}$ : heated by $6^{\circ} \mathrm{C}$ ) to manipulate biodiversity by temperature stress and use the resultant communities as inocula for the second step, the analysis of responses to salinity. First, autumn plankton from Kiel Bight, Baltic Sea (sampled on 28 October 2015) and early summer plankton from Thermaikos Bay, Mediterranean Sea (sampled on 16 June 2015) were taken and metazoan grazers were removed by sieving through a $200 \mu \mathrm{m}$ mesh size gauze. Temperature in the heated treatments was increased gradually over 3 days $\left(+2^{\circ} \mathrm{C}\right.$ per day) and was kept at $+6^{\circ}$ above ambient for another 3 days. The resultant $\mathrm{A}_{\mathrm{i}}$ and $\mathrm{H}_{\mathrm{i}}$ communities where used as inoculum for the second step. Using a single unit for each temperature pre-treatment assured identical starting conditions between the different mesocosms for the subsequent salinity experiment. For the Baltic Sea experiment $7.5 \mathrm{ml}$ of the $A_{i}$ were added to each mesocosm of the A community and $10 \mathrm{ml}$ of the $\mathrm{H}_{\mathrm{i}}$ to each mesocosm of the $\mathrm{H}$ community; for the Mediterranean experiment $9.1 \mathrm{ml}$ of the $A_{i}$ were added to each mesocosm of the A community and $10 \mathrm{ml}$ of the $\mathrm{H}_{\mathrm{i}}$ to each mesocosm of the $\mathrm{H}$ community. The second step consisted of 24 outdoor mesocosms (two experimental communities preconditioned by different temperatures $\times$ three salinity levels $\times$ four replicates, Table 1) with a volume of $15 \mathrm{~L}$ each. Mesocosms were filled with sterile filtered seawater $(0.2 \mu \mathrm{m})$ from the study and were inoculated with the $\mathrm{A}_{i}$ and $\mathrm{H}_{\mathrm{i}}$ communities. Inoculum volumes were adjusted to provide equal initial biomasses in all treatments. The experiments were terminated after all treatments reached stationary phase. For sample identification we use a code indicating the temperature pre-treatment $\left(\mathrm{A}_{\mathrm{i}}\right.$ and $\mathrm{H}_{\mathrm{i}}$, $\mathrm{i}$ subscript corresponds to start samples of the salinity treatment) and the salinity treatment $(\mathrm{f}-, \mathrm{f}$, and $\mathrm{f}+$ for low, ambient and high salinity; f subscript corresponds to end-point samples of the salinity treatment). Thus, $\mathrm{A}_{\mathrm{i}}$ and $\mathrm{H}_{\mathrm{i}}$ are at the same time the end-point samples for the temperature pre-treatment and the start samples for the salinity treatment, $\mathrm{A}_{\mathrm{f}}, \mathrm{A}_{\mathrm{f}+}, \mathrm{A}_{\mathrm{f}-}, \mathrm{H}_{\mathrm{f}}, \mathrm{H}_{\mathrm{f}+}$, and $\mathrm{H}_{\mathrm{f}-}$ are the end point samples for the salinity treatments.

\section{Sample Collection}

Water temperature, salinity and fluorescence (fluorometer 10AU, Turner Design) in the Baltic mesocosms were measured every second day during the first week and every day after the first week of the experiment. In the Mediterranean experiment, phytoplankton abundance was measured instead of fluorescence using the inverted microscope method (Utermöhl, 1958). At the end of the experiments, subsamples (48 samples) were analyzed with the inverted microscope and morphospecies richness, abundance and biomass showed no significant differences among the replicates according to Kolmogorof-Smirnov statistical test. For the molecular analysis, subsamples of $100 \mathrm{~mL}$ were taken from each replicate for DNA and RNA sequencing before the inoculation and at the end of the salinity experiment. After collection, DNA and RNA samples were filtered immediately through $0.2 \mu \mathrm{m}$ nucleopore filters ( $47 \mathrm{~mm}$ diameter) using very low filtration pressure. The filters were stored at $-80^{\circ} \mathrm{C}$ until nucleic acid extraction.

\section{DNA and RNA Extraction}

Filters of the same replicates were pooled together before DNA and RNA extraction, based on microscopy data that showed no significant differences between replicates in terms of morphospecies richness, abundance and biomass. Nucleic acid extractions were done using PowerWater DNA isolation kit (Mo Bio Laboratories Inc., Carlsbad, CA, United States) and PowerSoil RNA isolation kit (Mo Bio Laboratories Inc., Carlsbad, CA, United States), following the manufacturers protocol. Minor modifications included introduction of three cycles of freezethaw $\left(-80^{\circ} \mathrm{C}, 5 \mathrm{~min}, 65^{\circ} \mathrm{C}, 5 \mathrm{~min}\right)$ and beat beading with $2 \times 5$ min intervals on a horizontal vortex. The RNA samples were tested for the presence of DNA contamination by PCR and then reversed-transcribed using qPCRBIO cDNA Synthesis Kit (PCR Biosystems, United Kingdom). The nucleic acid samples contained between $3.2 \mathrm{ng} \mathrm{u} \mathrm{L}^{-1}$ and $25.8 \mathrm{ng} \mathrm{u} \mathrm{L}^{-1}$ of total DNA and between $3.1 \mathrm{ng} \mathrm{u} \mathrm{L}^{-1}$ and $16.4 \mathrm{ng} \mathrm{u} \mathrm{L}^{-1}$ of total RNA as measured by NanoDrop (Thermo Scientific, United States).

\section{PCR and Tag Pyrosequencing}

Tag pyrosequencing of $18 \mathrm{~S}$ rDNA was performed using PCR amplification of the $\mathrm{V} 2$ and $\mathrm{V} 3$ region and by using the two eukaryotic primers 18S-82F (5'-GAAACTGCGAATGGCTC-3') (Lopez-Garcia et al., 2003) and Euk-516r (5'-ACCAGA CTTGCCCTCC-3') (Amann et al., 1990). These primers were designed to amplify $470-480$ bp in the region. Furthermore, cDNA (representing RNA) was amplified using the same primer pair targeting the same region. PCR reactions and barcode amplicon sequencing process described by Dowd et al. (2008) was performed by the Mr. DNA Company (Shallowater, TX, United States) ${ }^{1}$. Briefly, PCR conditions included a denaturation step at $95^{\circ} \mathrm{C}$ for $5 \mathrm{~min}, 30$ cycles of amplification that were performed at $95^{\circ} \mathrm{C}$ for $30 \mathrm{~s}, 50^{\circ} \mathrm{C}$ for $30 \mathrm{~s}$ and $72^{\circ} \mathrm{C}$ for $1 \mathrm{~min}$. A final extension step was performed for $7 \mathrm{~min}$ at $72^{\circ} \mathrm{C}$. Subsequently, PCR products were purified using calibrated Ampure XP beads and the purified products were used to prepare the DNA libraries by following the Illumina MiSeq DNA high-throughput library preparation protocol. DNA library preparation and sequencing was performed at $\mathrm{Mr}$.

\footnotetext{
${ }^{1}$ http://mrdnalab.com/
} 
TABLE 1 | General description of A and H communities treatments, and number of DNA and RNA-based OTUs for each experiment.

\begin{tabular}{|c|c|c|c|c|c|c|c|c|c|c|}
\hline \multirow[t]{2}{*}{ Code } & \multicolumn{2}{|c|}{ Time (days) } & \multicolumn{2}{|c|}{ Temperature $\left({ }^{\circ} \mathrm{C}\right)$} & \multicolumn{2}{|c|}{ Salinity (psu) } & \multicolumn{2}{|c|}{ DNA OTUs } & \multicolumn{2}{|c|}{ RNA OTUs } \\
\hline & Baltic & Mediterranean & Baltic & Mediterranean & Baltic & Mediterranean & Baltic & Mediterranean & Baltic & Mediterranean \\
\hline$A_{i}$ & $t=0$ & $t=0$ & 12.4 & 18.4 & 16.4 & 33.8 & 299 & 260 & 274 & 288 \\
\hline$A_{f}$ & $t=19$ & $t=16$ & 12.4 & 18.4 & 16.4 & 33.8 & 284 & 244 & 402 & 284 \\
\hline$A_{f+}$ & $t=19$ & $t=16$ & 12.4 & 18.4 & 21.4 & 38.8 & 176 & 239 & 385 & 276 \\
\hline$A_{f-}$ & $t=19$ & $t=16$ & 12.4 & 18.4 & 11.4 & 28.8 & 212 & 180 & 247 & 239 \\
\hline $\mathrm{H}_{\mathrm{i}}$ & $t=0$ & $t=0$ & 18.4 & 24.4 & 16.4 & 33.8 & 235 & 224 & 214 & 259 \\
\hline $\mathrm{H}_{f}$ & $t=19$ & $t=16$ & 18.4 & 24.4 & 16.4 & 33.8 & 266 & 232 & 312 & 215 \\
\hline $\mathrm{H}_{\mathrm{f}+}$ & $t=19$ & $t=16$ & 18.4 & 24.4 & 21.4 & 38.8 & 135 & 221 & 240 & 194 \\
\hline $\mathrm{H}_{\mathrm{f}-}$ & $t=19$ & $t=16$ & 18.4 & 24.4 & 11.4 & 28.8 & 211 & 215 & 200 & 184 \\
\hline
\end{tabular}

Values for the Mediterranean experiment are shaded.

DNA (Shallowater, TX, United States) ${ }^{2}$ on a MiSeq following the manufacturer's guidelines. Sequences were submitted to GenBank-SRA under the accession number SRX3222420.

\section{Read Processing}

The produced reads were processed using MOTHUR v 1.34.0 software following the standard operating procedure (Schloss et al., 2009, 2011). Briefly, forward and reverse reads were joined, and the barcodes were removed. Reads $<200 \mathrm{bp}$, with homopolymers $>8$ bp or with ambiguous base calls were removed from downstream analysis. The remaining reads were dereplicated to the unique sequences and aligned independently against SILVA 128 database, containing 140,020 eukaryotic SSU rRNA sequences (Quast et al., 2013). Then, reads suspected of being chimeras were removed using the UCHIME software (Edgar, 2010). The data sets were normalized to the sample with the lowest number of reads using the subsample command in MOTHUR, so that rDNA samples contained 41,504 reads and rRNA samples 61,910 reads. These reads were clustered into OTUs at $97 \%$ sequence similarity threshold. Singletons were removed, as they were likely erroneous sequencing products (Kunin et al., 2010; Behnke et al., 2011). After the analyses, 2948 OTUs in rDNA samples and 2947 OTUs in rRNA samples were produced in total, and were taxonomically classified using BLASTN (Altschul et al., 1990) on the PR2 curated database, which contains protists sequences (Guillou et al., 2013). OTUs that were affiliated to Metazoa (eggs, larvae, fragments of animals) were removed, thus 1715 OTUs belonging to protists remained in rDNA samples and 1653 OTUs in rRNA samples.

\section{Assignment of Unicellular Eukaryotes in Functional/Trophic Groups}

All OTUs were assigned to six trophic groups according to their trophic roles (Supplementary Table 1), autotrophs (e.g., Bacillariophyceae), mixotrophs (e.g., Haptophyceae), micrograzers (e.g., Amoebozoa), picograzers [e.g., Marine stramenopile (MAST)], parasites [e.g., Marine alveolates (MALVs)] and decomposers (e.g., Fungi). Briefly, each OTU was individually examined and assigned to one of the six

${ }^{2}$ www.mrdnalab.com groups after gathering the current available information for it. Microscopic observations (phase contrast and epifluoresence microscopy) were also used for the classification and assignment of every microscopically detectable OTU (e.g., Skeletonema, Prorocentrum, Imantonia). For the rest OTUs which were undetectable with microscopic techniques (e.g., MALVs, Pirsonia), the assignment was done according to extensive literature search (Supplementary Table 1). For instance, MALVs and Pirsonia are classified as parasites (Skovgaard, 2014) and Picobilyphyta are classified as picograzers (Moreira and López-García, 2014).

\section{Data Analysis}

Rarefaction curves for all samples were calculated with the PAST $2.17 \mathrm{c}$ software, in order to determine if the sequencing effort was sufficient to fully assess the OTUs richness. The ratios of auto- and mixotrophic to heterotrophic OTUs $\left(\mathrm{S}_{\text {auto }} / \mathrm{S}_{\text {het }}\right)$ and auto- and mixotrophic to consumers number of OTUs $\left(S_{\text {auto }} / S_{\text {grazers }}+\right.$ parasites $)$ were calculated as metrics related to the community trophic structure. Decomposers were excluded from the calculation of the $S_{\text {auto }} / S_{\text {grazers }}+$ parasites ratio as they did not consume living biomass. OTUs were grouped into two categories according to their relative abundance. Per sample abundant OTUs were defined as those with relative abundance $>1 \%$ of the total number of reads in the sample while per sample rare as those with relative abundance $<0.2 \%$ (Mangot et al., 2013; Logares et al., 2014; Genitsaris et al., 2015). For defining overall abundant and rare OTUs the aforementioned thresholds were divided by a factor of 10; overall abundant OTUs were represented with $>0.1 \%$ of the total number of reads while overall rare with $<0.02 \%$ of the total number of reads (Logares et al., 2014; Genitsaris et al., 2015). The relationship between $18 \mathrm{~S}$ rRNA and $18 \mathrm{~S}$ rDNA frequency was examined for each common OTU in the two datasets of rDNA and rRNA. rRNA:rDNA ratios were used as a proxy in order to examine the relative activity of the obtained OTUs. First, the range of rRNA:rDNA ratio was calculated for the taxonomic groups and then the average rRNA:rDNA ratio for each taxonomic and for each trophic group was calculated across the treatments in order to evaluate the alterations in relative activity in relation to temperature and salinity changes. The resistance of $\mathrm{A}$ and $\mathrm{H}$ communities to salinity change was measured by $\log$-response ratio $[\mathrm{LR}=\ln (\mathrm{Y} 1 / \mathrm{Y} 0)]$, where $\mathrm{Y} 1$ is 
the metric of choice in the treatments $\left(\mathrm{A}_{\mathrm{f}-}, \mathrm{A}_{\mathrm{f}+}, \mathrm{H}_{\mathrm{f}-}, \mathrm{H}_{\mathrm{f}+}\right)$ and $\mathrm{Y} 0$ the metric of choice in the control $\left(\mathrm{A}_{\mathrm{f}}, \mathrm{H}_{\mathrm{f}}\right)$. A LR close to zero indicates little change, while strongly positive or negative ratios indicate strong change. As metrics of response, we chose the two most important measures of diversity, OTU-richness (S), and evenness (E) (Wilsey and Potvin, 2000) and two measures of trophic structure, $S_{\text {auto }} / S_{\text {het }}$ and $S_{\text {auto }} / S_{\text {grazers }}+$ parasites .

\section{Statistical Analysis}

Non-parametric Kolmogorov-Smirnov paired test (K-S test) was used to evaluate whether the rDNA and rRNA relative abundance between $A_{i}$ and $H_{i}$ unicellular eukaryotic communities are equal. The equality among the rDNA and rRNA relative abundance across the three salinities was examined with non-parametric Kruskal-Wallis test. The significance of heat shock and salinity changes effect on taxonomic composition across the treatments was tested with Pearson's chi-square test. Kendall rank correlation coefficient was used to measure the ordinal association between $18 \mathrm{~S}$ rDNA and $18 \mathrm{~S}$ rRNA relative abundance. Finally, we used multidimensional scaling (MDS) based on Jaccard similarity coefficient, due to its sensitivity for the rare taxa (Chao et al., 2005), to compare the community composition.

\section{RESULTS}

\section{rDNA and rRNA Community Structure}

A total of 1715 unique OTUs, were identified over all samples after read denoising, chimera removal, removal of metazoan OTUs and normalization. These were affiliated to 9 protistan supergroups (Alveolates, Amoebozoa, Apusozoa, Excavata, Archeoplastida, Hacrobia, Opisthoconta, Rhizaria, Stramenopiles) and were further divided into 36 taxonomic groups. Two hundreds and thirty-seven OTUs were shared in both experiments while 639 OTUs were observed only in the Baltic experiment and 839 OTUs only in the Mediterranean experiment. Among the 36 taxonomic groups in the Baltic experiment, Bacillariophyceae had the highest number of OTUs (382) followed by Fungi (275 OTUs) and Dinophyceae (248 OTUs) (Figure 1). Regarding the trophic groups, autotrophs had the highest OTU richness (374) followed by picograzers (166 OTUs) and parasites (124 OTUs) (Supplementary Table 2B). In the Mediterranean experiment, Dinophyceae was the taxonomic group with the highest number of OTUs (403) followed by Fungi (239 OTUs) and Bacillariophyceae (178 OTUs) (Figure 1) and mixotrophs were the trophic group with the highest OTU richness (298) followed by picograzers (270 OTUs) and parasites (212 OTUs) (Supplementary Table 2B). The RNA dataset was composed by 1653 unique OTUs. In the Baltic experiment, Bacillariophyceae prevailed as the most abundant taxonomic group (289,044 reads-56\%) followed by Haptophyceae (74,696 reads-15\%) and Fungi (25,128 reads5\%) (Supplementary Table 2A). Autotrophs were the most abundant trophic group (304,766 reads-59\%) followed by picograzers $(95,264$ reads-19\%) and mixotrophs $(74,443$ reads14\%) (Figure 1). In the Mediterranean experiment, Fungi were the most abundant taxonomic group (182,643 reads-38\%) followed by Dinophyceae (48,784 reads-10\%) and Haptophyceae (21,723 reads-5\%) (Supplementary Table $2 \mathbf{A})$ and decomposers were the most abundant trophic group (180,643 reads-38\%) followed by picograzers (149,458 reads-31\%) and autotrophs $(76,153$ reads-16\%) (Figure 1). Finally, rarefaction curves reached a plateau in all cases when $\geq 97 \%$ cutoff levels of read similarities were applied (Supplementary Figure 1) both in DNA and RNA analyses.

\section{Effects of Changing Salinity on A and H Microeukaryotic Community Structure}

According to K-S paired test equality between the $\mathrm{A}_{\mathrm{i}}$ and $\mathrm{H}_{\mathrm{i}}$ communities was rejected in both experiments $\left(P_{\text {same }}>0.05\right)$ and according to chi-square test the effect of the heat shock on community composition was statistically significant in both cases $\left(P_{\text {Pearson's }}<0.05\right)$. Totally, in the Baltic experiment 299 DNA-based OTUs were identified in $\mathrm{A}_{\mathrm{i}}$ community and 235 in $\mathrm{H}_{\mathrm{i}}$ community and in the Mediterranean experiment 260 in $\mathrm{A}_{\mathrm{i}}$ and 224 in $\mathrm{H}_{\mathrm{i}}$ (Table 1). Eighty-one Bacillariohyceae related DNA-based OTUs were recorded in $\mathrm{A}_{\mathrm{i}}$ in the Baltic experiment while only 50 in $\mathrm{H}_{\mathrm{i}}$ (Figure 2A). Their RNAbased relative abundance decreased from $48 \%$ in $\mathrm{A}_{\mathrm{i}}$ to $41 \%$ in $\mathrm{H}_{\mathrm{i}}$ (Figure 2A). Autotrophic DNA-based OTUs and RNAbased reads decreased from 109 and $50 \%$ in $A_{i}$ to 69 and $42 \%$ in $\mathrm{H}_{\mathrm{i}}$ (Figure 3A). In the Mediterranean experiment $\mathrm{A}_{\mathrm{i}}$ contained 175 Dinophyceae related DNA-based OTUs while $\mathrm{H}_{\mathrm{i}}$ only 72 (Figure $2 \mathbf{B}$ ). Their RNA-based relative abundance deceased from $30 \%$ in $\mathrm{A}_{\mathrm{i}}$ to $23 \%$ in $\mathrm{H}_{\mathrm{i}}$ (Figure 2B). Autotrophs together with mixotrophs had 20 less DNA-based OTUs and $18 \%$ less RNA-based reads in $\mathrm{H}_{i}$ than in $\mathrm{A}_{\mathrm{i}}$ (Figure 3B). On the other hand, a relatively low increase of Chlorophyceae and Haptophyceae related DNA-based OTUs was detected in $\mathrm{H}_{\mathrm{i}}$ in both experiments (Figures 2A,B). Furthermore, increased DNA-based OTU richness and RNA-based relative abundance was found for Fungi and decomposers in $\mathrm{H}_{\mathrm{i}}$ in the Baltic experiment and for MAST and picograzers in the Mediterranean experiment (Figures 2A,B, 3A,B). The rest of the taxonomic and trophic groups did not show considerable differences. As less autotrophs and more heterotrophs and parasites were found in $\mathrm{H}_{\mathrm{i}}$ in both experiments, the ratios $\mathrm{S}_{\text {auto }} / S_{\text {het }}$ and $S_{\text {auto }} / S_{\text {grazers }}+$ parasites were lower than in $A_{i}$ (Supplementary Table 3).

Bacillariophyceae-related OTUs in the Baltic experiment had the highest DNA-based diversity and RNA-based relative abundance in $\mathrm{A}_{\mathrm{f}-}$ and in $\mathrm{H}_{\mathrm{f}-\text {; }} 20$ more DNA-based OTUs were

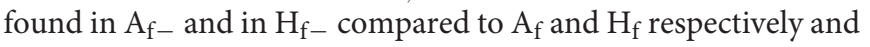
$40 \%$ higher RNA-based relative abundance in $\mathrm{A}_{\mathrm{f}-\text { than }} \mathrm{A}_{\mathrm{f}}$ and $2 \%$ higher in $\mathrm{H}_{\mathrm{f}-}$ than $\mathrm{H}_{\mathrm{f}}$ (Figure 2A). The highest autotrophic DNA-based OTU richness and RNA relative abundance were observed also in $\mathrm{A}_{\mathrm{f}-}$ and $\mathrm{H}_{\mathrm{f}-} ; 10$ more DNA-based OTUs and $39 \%$ more RNA-based reads were recorded in $\mathrm{A}_{\mathrm{f}-\text { compared to }}$ $\mathrm{A}_{\mathrm{f}}$ and 20 and $1.5 \%$ more in $\mathrm{H}_{\mathrm{f}-}$ compared to $\mathrm{H}_{\mathrm{f}}$ (Figure 3A). High salinity had little effect on Bacillariophyceae and autotrophs as the DNA-based OTUs and the RNA-based reads between $\mathrm{A}_{\mathrm{f}}$ and $\mathrm{A}_{\mathrm{f}+}$ and $\mathrm{H}_{\mathrm{f}}$ and $\mathrm{H}_{\mathrm{f}+}$ were similar (Figures 2A, 3A). 


\section{Taxonomic Groups - Number of DNA-based OTUs \\ Baltic Sea \\ Mediterranean Sea}

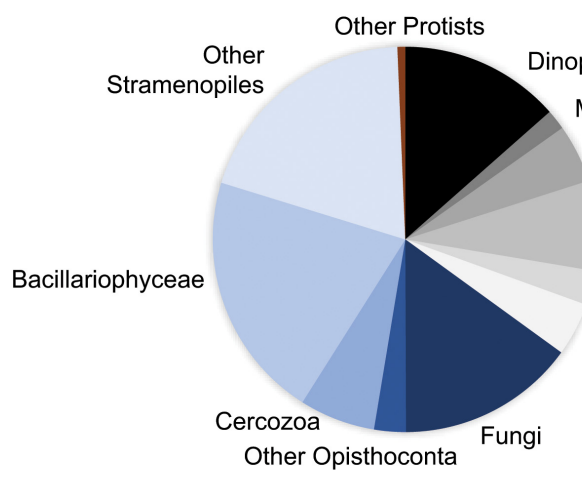

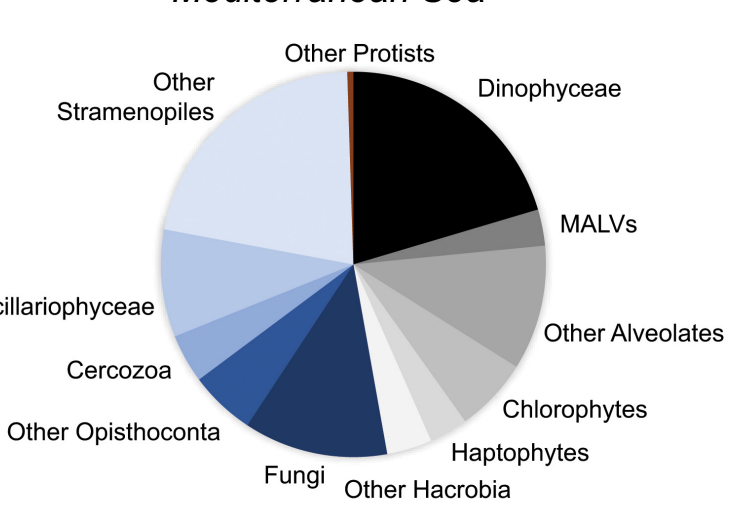

\section{Trophic Groups - Number of RNA-based Reads Baltic Sea Mediterranean Sea}
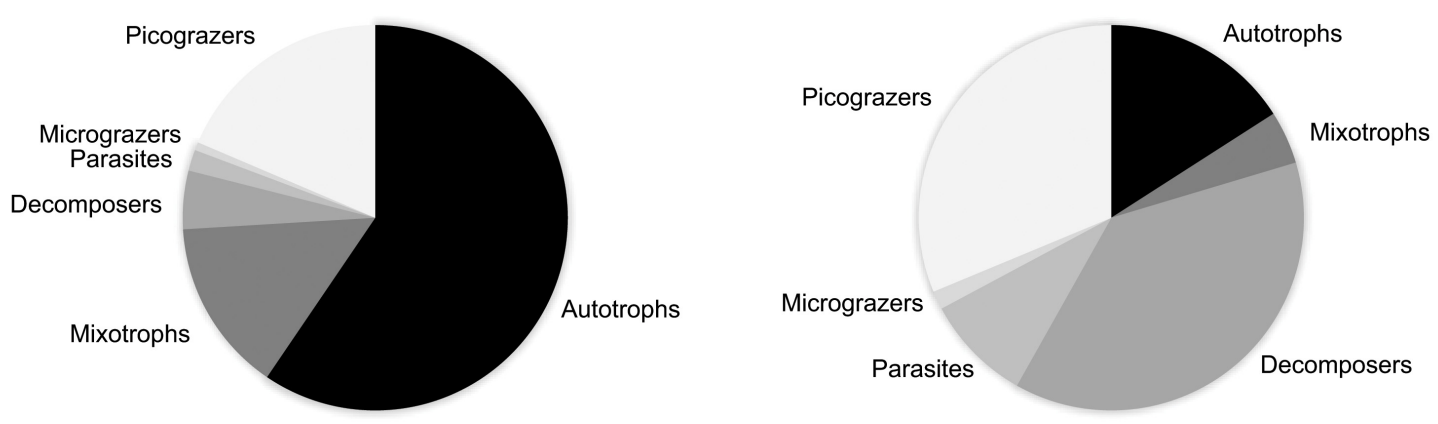

FIGURE 1 | Pie charts of the number of DNA-based OTUs of taxonomic groups, and number of RNA-based reads of trophic groups detected in the Baltic Sea and Mediterranean Sea experiments.

The highest values of the $S_{\text {auto }} / S_{\text {het }}$ and $S_{\text {auto }} / S_{\text {grazers }}+$ parasites ratios were also calculated in $\mathrm{A}_{\mathrm{f}}$ - and in $\mathrm{H}_{\mathrm{f}}$ - while they were similar between $\mathrm{A}_{\mathrm{f}}$ and $\mathrm{A}_{\mathrm{f}+}$ and almost similar between $\mathrm{H}_{\mathrm{f}}$ and $\mathrm{H}_{\mathrm{f}+}$ (Supplementary Table 3). In the Mediterranean experiment salinity changes affected Dinophyceae differently depending on heat shock application. Dinophyceae had 20 more DNA-based OTUs and $8 \%$ more RNA-based reads in $\mathrm{A}_{\mathrm{f}}$ and $\mathrm{A}_{\mathrm{f}}$ - than $\mathrm{A}_{\mathrm{f}}$ but they had 29 less DNA-based OTUs but still 3\% more RNAbased reads in $\mathrm{H}_{\mathrm{f}+}$ and $\mathrm{H}_{\mathrm{f}-}$ than $\mathrm{H}_{\mathrm{f}}$ (Figures 2B, 3B). The highest autotrophic and mixotrophic DNA-based OTU richness and RNA-based relative abundance was observed in $\mathrm{A}_{\mathrm{f}+}$ and the lowest in $\mathrm{H}_{\mathrm{f}-}$ (Figure 3B). $\mathrm{S}_{\text {auto }} / \mathrm{S}_{\text {het }}$ and $\mathrm{S}_{\text {auto }} / \mathrm{S}_{\text {grazers }}+$ parasites ratios increased in $\mathrm{A}_{\mathrm{f}}$ and $\mathrm{H}_{\mathrm{f}}$ compared to $\mathrm{A}_{\mathrm{f}}$ and $\mathrm{H}_{\mathrm{f}}$ and remained almost stable between $\mathrm{A}_{\mathrm{f}-}$ and $\mathrm{A}_{\mathrm{f}}$ and $\mathrm{H}_{\mathrm{f}-}$ and $\mathrm{H}_{\mathrm{f}}$ (Supplementary Table 3).

A low number of shared DNA-based OTUs was found among the different salinity treatments of each community in both experiments. In the Baltic experiment 80 shared OTUs out of 452 were found in the A community and 63 out of 425 were found in the $\mathrm{H}$ community while in the Mediterranean experiment 60 out of 387 and 89 out of 540 were found respectively (Supplementary Figure 2).
The Kruskal-Wallis test indicated that there was no equality among the different salinity treatments $(P>0.05)$ in both experiments. However, according to the chi-squared test, the effect of salinity changes to community composition was statistically not significant $\left(P_{\text {Pearosn's }}>0.05\right)$. Fungal OTUs together with Bacillariophyceae and Dinophyceae made up the $46 \%$ of the shared OTUs in A community in the Baltic experiment and $58 \%$ in Mediterranean experiment while the rest of the taxonomic groups contributed with $<10 \%$ each. In terms of DNA-based relative abundance the genera Kappamyces (98\% similarity), Skeletonema (100\% similarity) and Gyrodinium (100\% similarity) in the Baltic experiment and genera of the class Exobasidiomycetes (100\% similarity), the genera Gyrodinium (100\% similarity) and Chaetoceros (100\% similarity) in the Mediterranean experiment were dominant shared OTUs. In the $\mathrm{H}$ community, OTUs related to Bacillariophyceae, to Dinophyceae and to Chlorophyceae made up $42 \%$ of the shared in the Baltic experiment while in the Mediterranean experiment Fungi, Dinophyceae and Bacillariophyceae made up 39\% of the shared. OTUs associated with the genera Skeletonema (100\% similarity), Gymnodinium (100\% similarity) and Desmochloris ( $100 \%$ similarity) in the Baltic experiment and with the genera 


\section{A}

\begin{tabular}{|c|c|}
\hline \multirow[b]{2}{*}{ Alveolata } & Dinophyceae \\
\hline & MALV \\
\hline \multirow{3}{*}{ Stramenopiles } & Other Alveolata \\
\hline & Bacillariophyceae \\
\hline & Other Stramenopiles \\
\hline Archaeoplastida & Chlorophyta \\
\hline \multirow{2}{*}{ Hacrobia } & Haptophyta \\
\hline & Other Hacrobia \\
\hline \multirow{2}{*}{ Opisthokonta } & Fungi \\
\hline & Other Opisthokonta \\
\hline Rhizaria & Cercozoa \\
\hline Others & \\
\hline
\end{tabular}

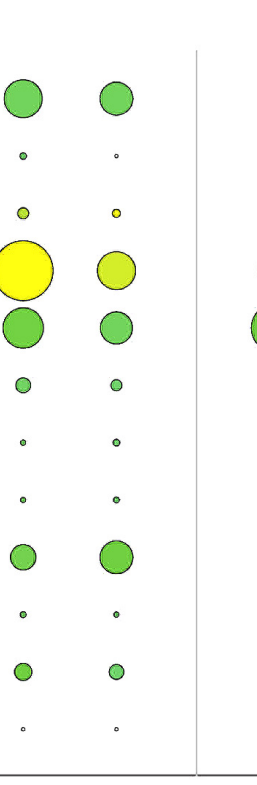

$\mathrm{Ai} \quad \mathrm{Hi} \quad \mathrm{Af} \quad \mathrm{Af}+\mathrm{Af}-\mathrm{Hf} \mathrm{Hf}+\mathrm{Hf}-$

\section{Treatments}

\section{Baltic Sea}

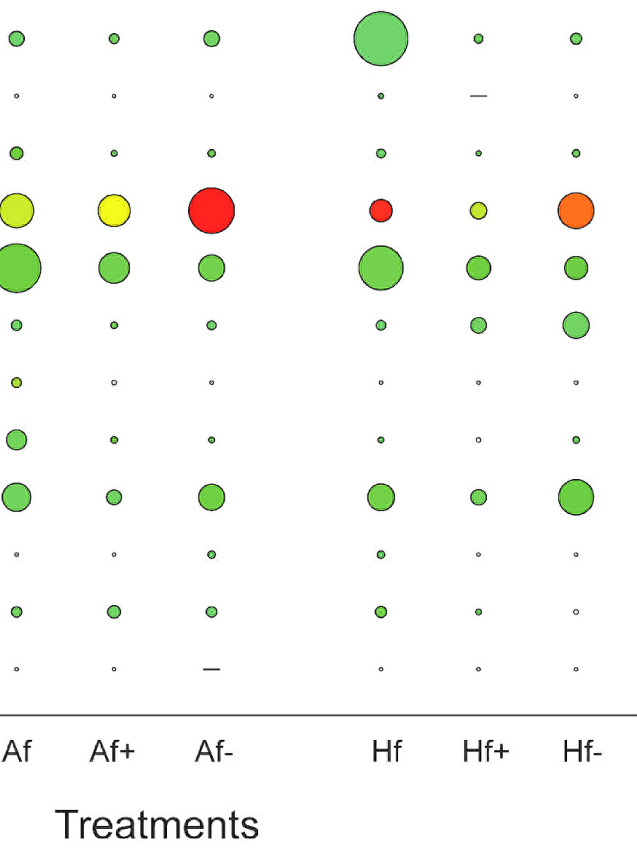

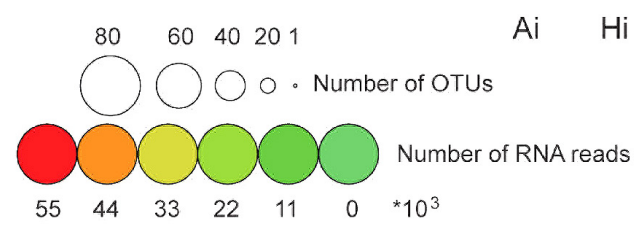

$\mathbf{B}$

Mediterranean Sea

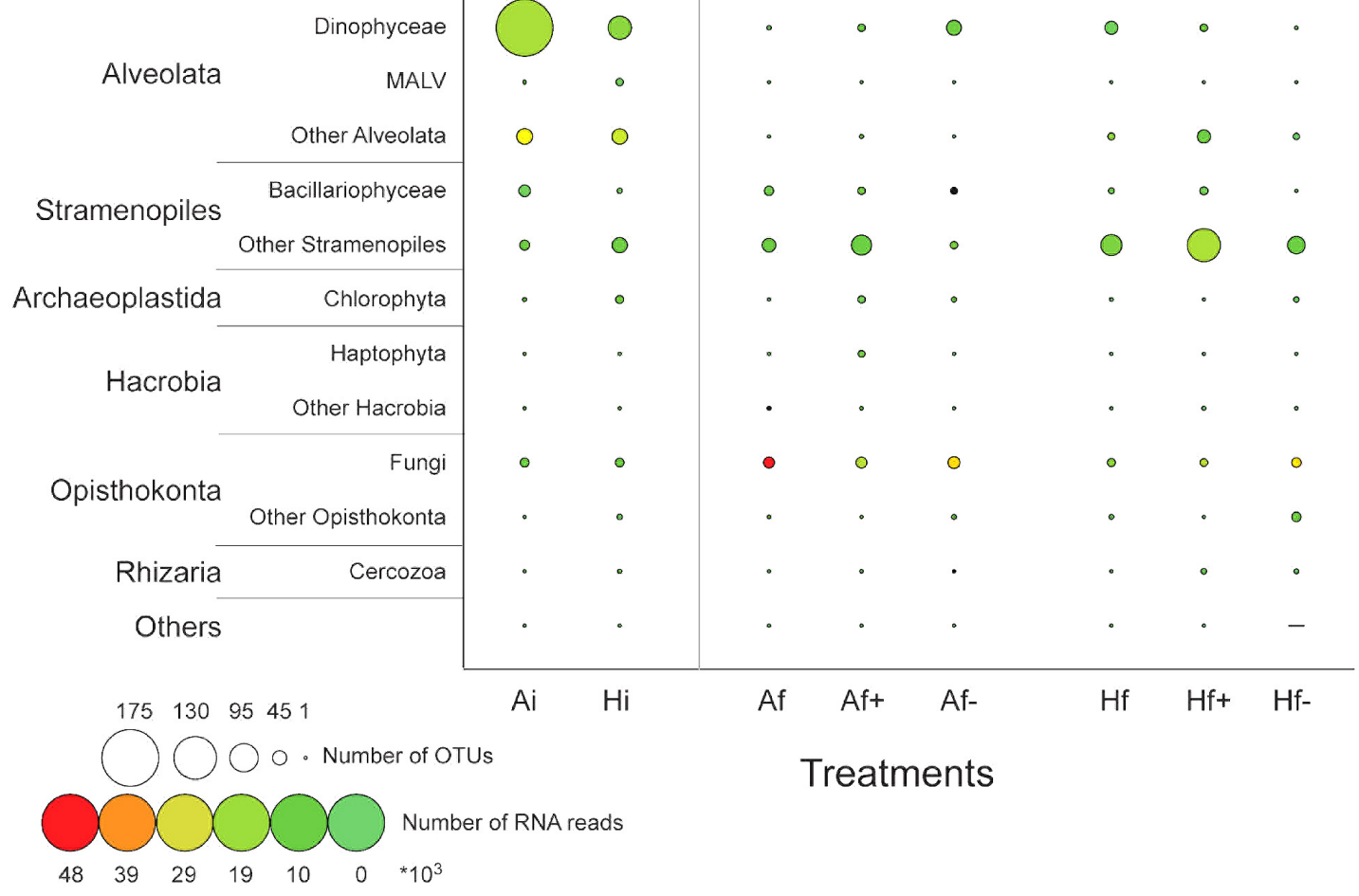

FIGURE 2 | Variation of the number of DNA-based OTUs (circle diameter) and the relative abundance (circle color) of RNA-based reads belonging to the dominant high-level taxonomic groups in the Baltic experiment (A) and in the Mediterranean experiment (B). The taxonomic affiliation was based on BLASTN searches against the PR2 database. $A_{i}$, initial sample and ambient temperature; $A_{f}$, ambient temperature and salinity; $A_{f+}$, ambient temperature and high salinity (+5 psu); $A_{f-}$, ambient temperature and low salinity ( $-5 \mathrm{psu}) ; \mathrm{H}_{\mathrm{i}}$, initial sample and heat shock $\left(+6^{\circ} \mathrm{C}\right)$; $\mathrm{H}_{\mathrm{f}}$, heat shock $\left(+6^{\circ} \mathrm{C}\right)$ and ambient salinity; $\mathrm{H}_{\mathrm{f}+}$, heat shock $\left(+6^{\circ} \mathrm{C}\right)$ and high salinity ( $+5 \mathrm{psu}) ; \mathrm{H}_{-}$, heat shock $\left(+6^{\circ} \mathrm{C}\right)$ and low salinity ( $\left.-5 \mathrm{psu}\right)$. 
A

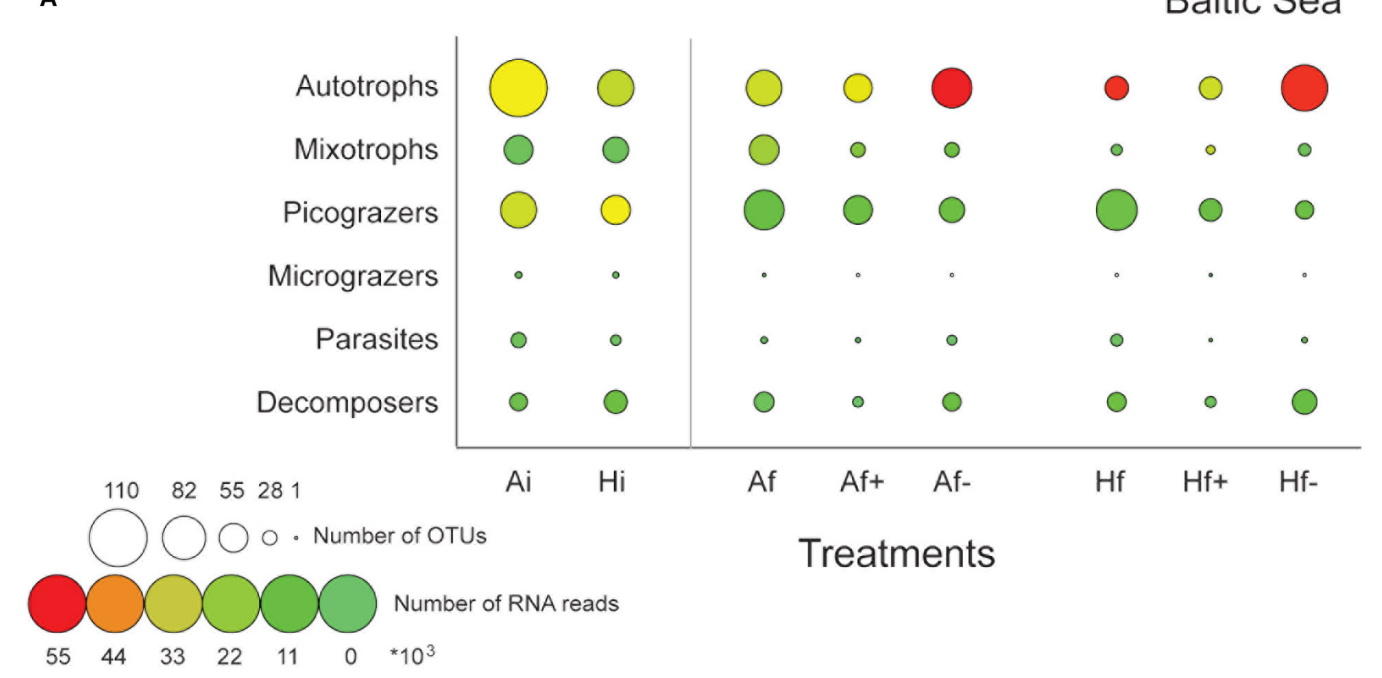

B

\section{Mediterranean Sea}

FIGURE 3 | Variation of the number of DNA-based OTUs (circle diameter) and the relative abundance (circle color) of RNA-based reads belonging to the six trophic groups in the Baltic experiment (A) and in the Mediterranean experiment (B). The assignment to the trophic groups was based on microscopic observations and literature data. $A_{i}$, inoculum and ambient temperature; $A_{f}$, ambient temperature and salinity; $A_{f+}$, ambient temperature and high salinity (+5 psu); $A_{f-}$, ambient temperature and low salinity $(-5 \mathrm{psu}) ; \mathrm{H}_{\mathrm{i}}$, inoculum and heat shock $\left(+6^{\circ} \mathrm{C}\right) ; \mathrm{H}_{\mathrm{f}}$, heat shock $\left(+6^{\circ} \mathrm{C}\right)$ and ambient salinity; $\mathrm{H}_{\mathrm{f}+}$, heat shock $\left(+6^{\circ} \mathrm{C}\right)$ and high salinity $(+5$ psu); $\mathrm{H}_{\mathrm{f}-}$, heat shock $\left(+6^{\circ} \mathrm{C}\right)$ and low salinity $(-5 \mathrm{psu})$.

of the class Exobasidiomycetes (100\% similarity), and the genera Scrippsiella (98\% similarity) and Chaetoceros (100\% similarity) in the Mediterranean experiment dominated in DNA-based relative abundance among the shared.

MDS showed a clear separation of plankton community composition between the two experiments (Figure 4). In the Mediterranean experiment, $\mathrm{A}_{\mathrm{i}}$ and $\mathrm{H}_{\mathrm{i}}$ communities exhibited major changes from the start to the end of the salinity treatments experiment whereas smaller changes were detected in the Baltic experiment. Nevertheless, salinity treatments in both experiments drove OTU composition in the same direction, irrespective of the temperature pre-treatment. This means, that for example pre-heated and unheated high salinity experimental communities became more similar among each other than experimental units with the same temperature pre-treatment but different salinity treatment.

\section{Relative Abundance and Inferred Activity of Taxonomic and Trophic Groups}

The proportions of rare and abundant OTUs were quite similar across the samples and rare OTUs dominated in both data sets (DNA-based and RNA-based) and in both experiments (Supplementary Table 4). Rare DNA-based OTUs in the Baltic experiment fluctuated between 83.9 and $88.4 \%$ of the total number of OTUs and rare RNA-based OTUs between 88 and $94.5 \%$ while abundant DNA-based OTUs fluctuated between 3.7 and 10.2\% and abundant RNA-based OTUs between 


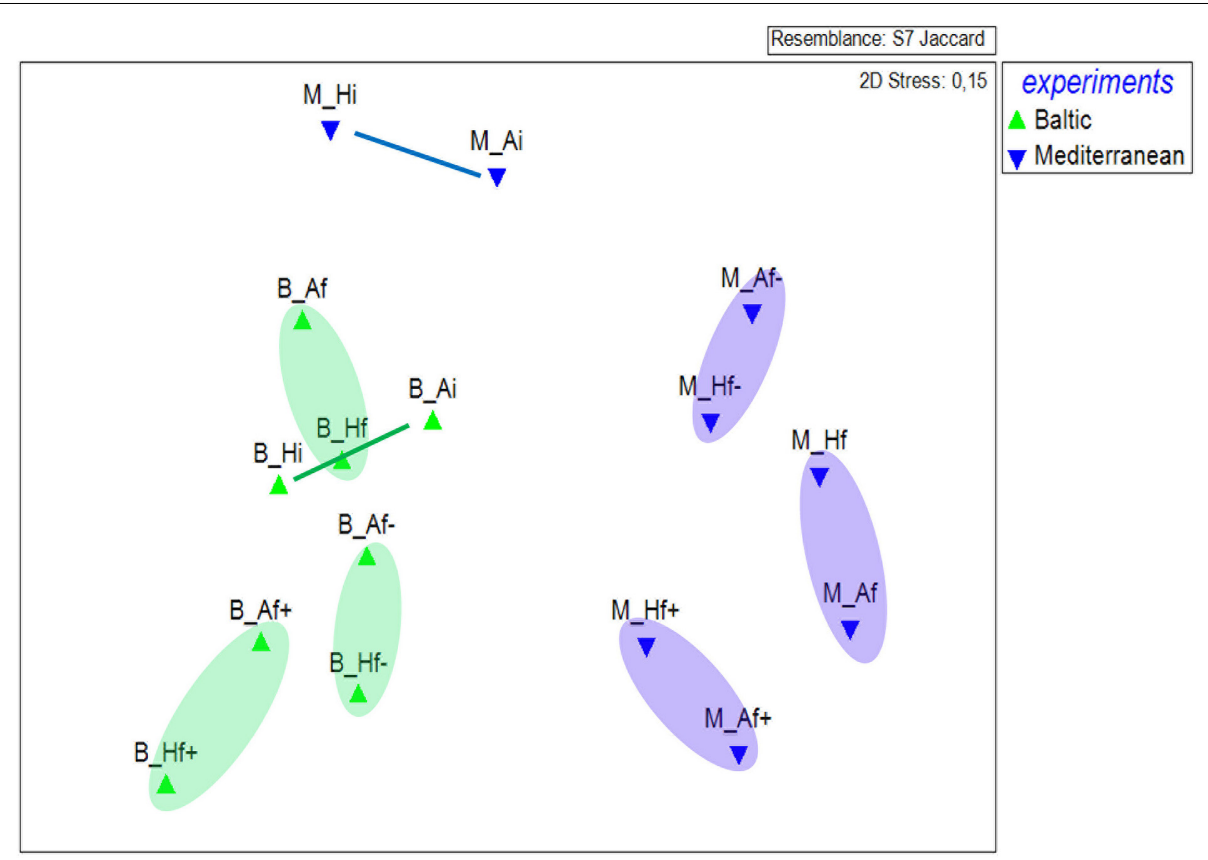

FIGURE 4 | Multidimensional scaling plot of read abundance variation in the different treatment assemblages, according to Jaccard similarity index, of the Baltic (B) and Mediterranean $(M)$ unicellular plankton communities. $A_{i}$, inoculum and ambient temperature; $A_{f}$, ambient temperature and salinity; $A_{f+}$, ambient temperature and high salinity (+5 psu); $A_{f-}$, ambient temperature and low salinity ( $\left.-5 \mathrm{psu}\right) ; \mathrm{H}_{\mathrm{i}}$, inoculum and heat shock $\left(+6^{\circ} \mathrm{C}\right) ; \mathrm{H}_{\mathrm{f}}$, heat shock $\left(+6^{\circ} \mathrm{C}\right)$ and ambient salinity; $\mathrm{H}_{\mathrm{f}+}$, heat shock $(+6 \mathrm{C})$ and high salinity $(+5 \mathrm{psu}) ; \mathrm{H}_{-}$, heat shock $\left(+6^{\circ} \mathrm{C}\right)$ and low salinity $(-5 \mathrm{psu})$.

1.5 and $4.6 \%$. Similarly, in the Mediterranean experiment rare DNA-based OTUs ranged from 77.4 to $91.7 \%$ and rare RNA-based OTUs from 79.4 to $88.8 \%$. Abundant DNA-based OTUs ranged from 3.3 to $10.9 \%$ and abundant RNA-based OTUs from 3.5 to $8.3 \%$. The abundant OTUs were affiliated mainly to 8 taxonomic groups (Dinophyceae, Bacillariophyceae, Haptophyceae, Chlorophyceae, Ciliophora, Fungi, Cercozoa and MAST).

In both experiments, the rRNA:rDNA relative abundance relationship revealed a positive correlation [Kendall correlation coefficient $\left(\tau_{\text {Baltic }}\right)=0.286, \tau_{\text {Mediterranean }}=0.328 ; P<0.001$ ] suggesting that the abundant OTUs in the DNA dataset were among the most abundant in RNA dataset and vice versa (Supplementary Figure 3). However, there were OTUs whose RNA relative abundance did not follow their DNA relative abundance. OTUs below the 1:1 line had a high DNA relative abundance but low RNA relative abundance (e.g., Heterocapsa, Gyrodinium, Desmochloris in the Baltic and Pelagodinium, Pelagostrobilidium, Chaetoceros in the Mediterranean) and OTUs above 1:1 line had low DNA relative abundance but high RNA relative abundance (e.g., Imantonia, Telonema in the Baltic and Phaeosphaeria, genera of the class Exobasidiomycetes in the Mediterranean).

The overall range of average RNA:DNA ratio showed large variability among taxonomic groups. The highest variation in the Baltic experiment was observed for Amoebozoa, Hacrobia excluding Haptophyceae (Centrohelioza, Cryptophyceae, Katablepharidota, Picobiliphyta, Telonemia), Apusozoa and Ciliophora and in the Mediterranean experiment for
Amoebozoa, Fungi and Haptophyceae (Supplementary Figure 4). On the contrary, the range of the estimated RNA:DNA ratio for Dinophyceae, Bacillariophyceae and Chlorophyceae and Bacillariophyceae, MALVs and Apusozoa respectively remained low.

In the Baltic experiment, similar rRNA:rDNA ratios were observed for Bacillariophyceae in $A_{i}$ and $H_{i}$ but reduced ratios were observed in $A_{f+}$ and $A_{f-}$ in comparison with $A_{f}$ and $\mathrm{H}_{\mathrm{f}+}$ and $\mathrm{H}_{\mathrm{f}-}$ in comparison with $\mathrm{H}_{\mathrm{f}}$ (Figure 5). The ratios for autotrophs were similar to Bacillariophyce including the decrease after salinity changes (Figure 6). In the Mediterranean experiment, increased rRNA:rDNA ratio was observed for Dinophyceae in $\mathrm{H}_{i}$ community compared to $\mathrm{A}_{\mathrm{i}}$ community and decreased ratios in $A_{f+}$ and $A_{f-}$ in comparison with $A_{f}$ and $\mathrm{H}_{\mathrm{f}+}$ and $\mathrm{H}_{\mathrm{f}-}$ in comparison with $\mathrm{H}_{\mathrm{f}}$ (Figure 5). The highest rRNA:rDNA ratios in the Baltic experiment were observed for Telonemia in $\mathrm{A}_{\mathrm{f}+}$ and $\mathrm{H}_{\mathrm{f}+}$. In the Mediterranean experiment, the highest rRNA:rDNA ratio was observed for Fungi in $\mathrm{H}_{\mathrm{f}}$ whose rRNA:rDNA ratios increased with salinity changes in both communities (Figure 5).

\section{Resistance}

In the Baltic experiment, OTU-richness responded more negatively to salinity increase $\left(\mathrm{A}_{\mathrm{f}+}, \mathrm{H}_{\mathrm{f}+}\right)$, while the temperature pre-treatment had little effect on resistance (Table 2). In the Mediterranean only $A_{f-}$ showed a clear negative response of OTU-richness to salinity decrease, while all other effects remained small. The negative response of evenness in the Baltic experiment was reversed compared to $S$, being stronger in $A_{f-}$ 


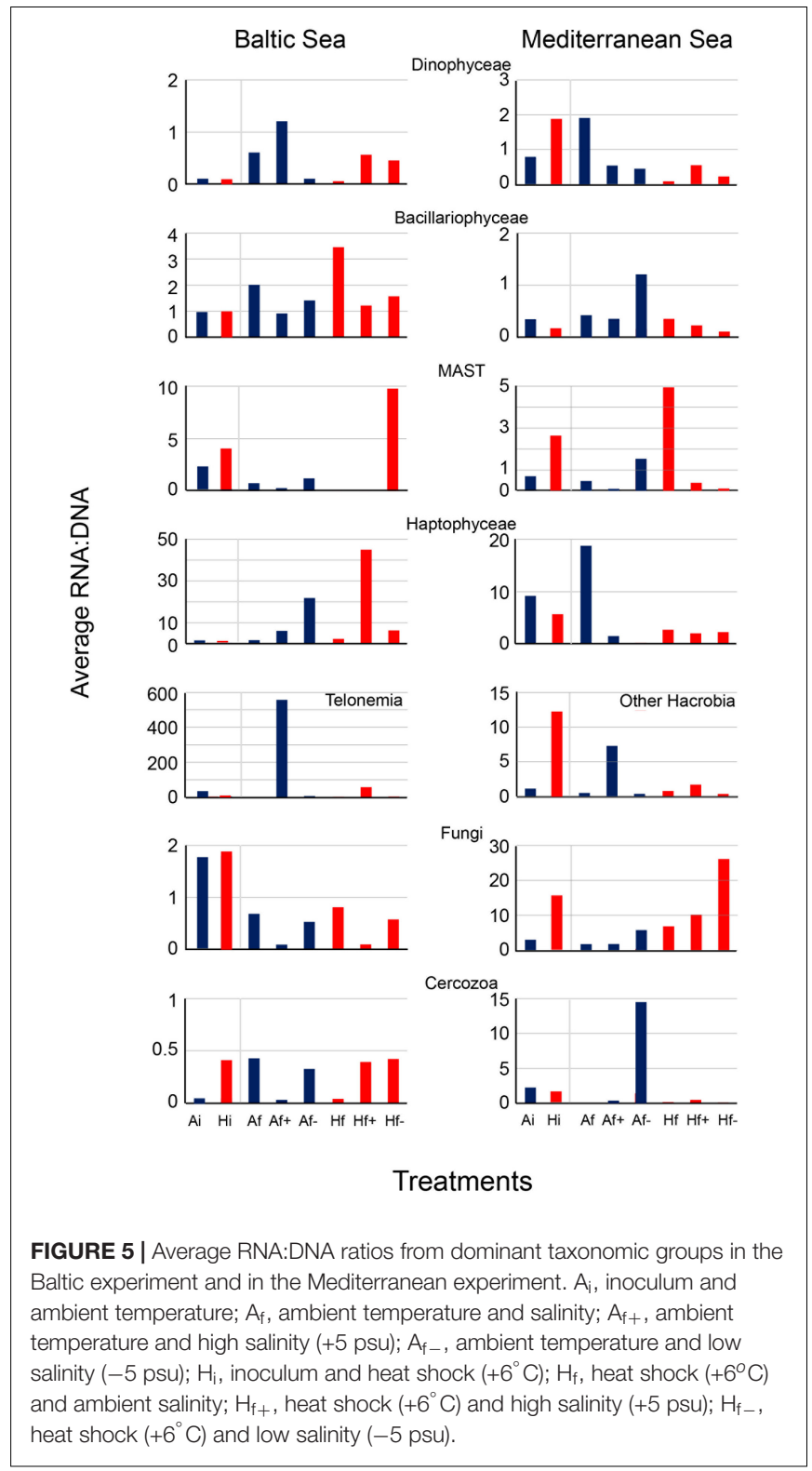

and $\mathrm{H}_{\mathrm{f}-}$. In the Mediterranean experiment, evenness remained relatively resistant only in the case of $\mathrm{A}_{\mathrm{f}+}$, while all other treatments showed a marked decrease. The two trophic structure indicators $\left(\mathrm{S}_{\text {auto }} / \mathrm{S}_{\text {het }}\right.$ and $\mathrm{S}_{\text {auto }} / \mathrm{S}_{\text {grazers }}+$ parasites ratios $)$ behaved similarly, with a strong increase in the pre-heated $\mathrm{H}_{\mathrm{f}+}$ and $\mathrm{H}_{\mathrm{f}-}$ in the Baltic experiment and in $\mathrm{A}_{\mathrm{f}+}$ and $\mathrm{H}_{\mathrm{f}+}$ in the Mediterranean experiment.

\section{DISCUSSION}

Our experimental results using sequential stressors, heat shock and salinity changes, demonstrate strong effects on OTU richness, community taxonomic and functional composition and rRNA:rDNA ratio of the Baltic and the Mediterranean plankton unicellular eukaryotes. We observed loss of OTUs together

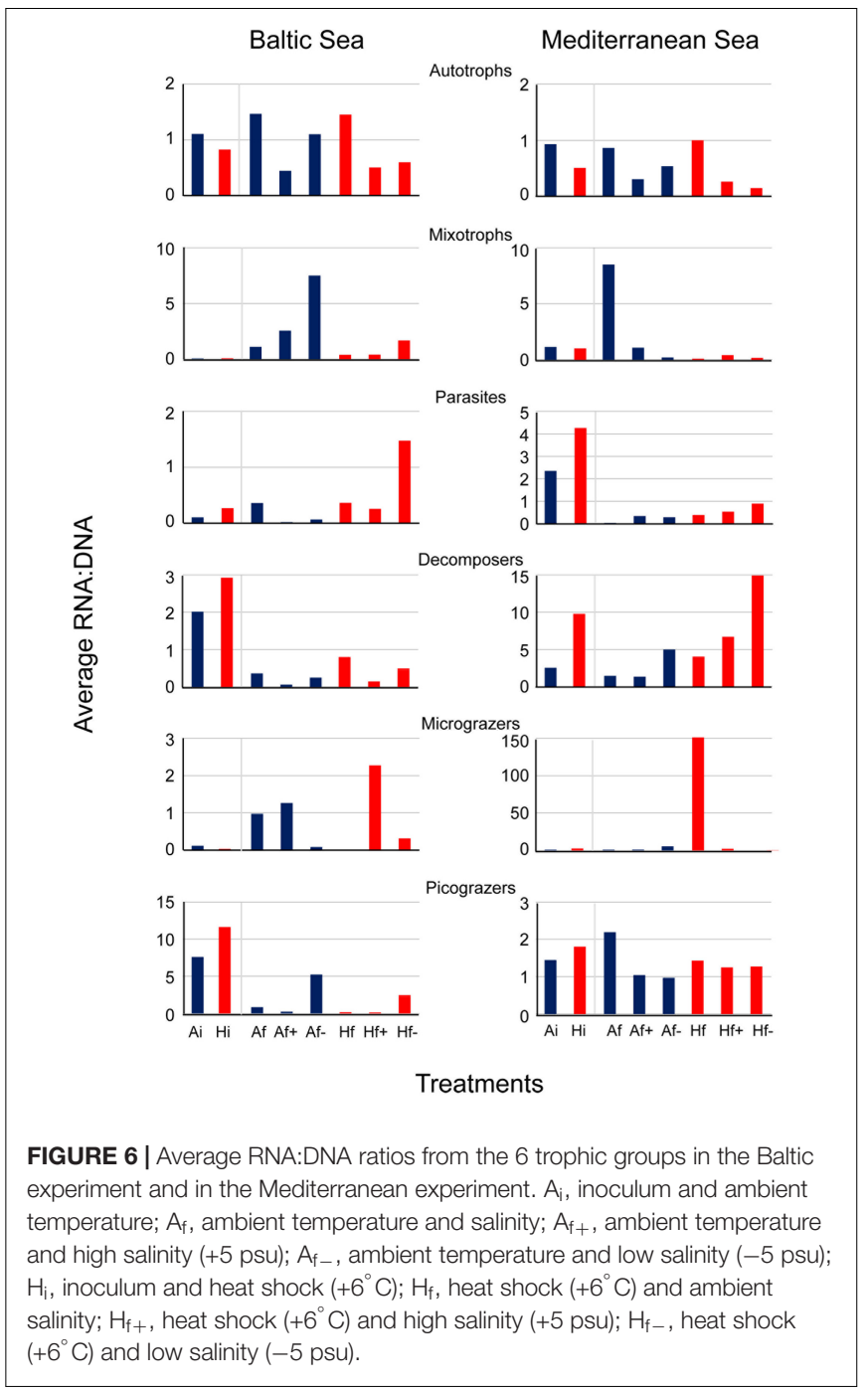

with significant compositional changes after the heat shock. At the same time increased rRNA:rDNA ratios for heterotrophic related OTUs were observed. Very few shared OTUs were found across the salinity treatments in each community; in the Baltic experiment reduced OTU richness were observed under high and low salinity while in the Mediterranean experiment under low salinity. We also found high variability on the response of rRNA:rDNA ratios after salinity changes among the taxonomic and trophic groups. The different effect of heating on the resistance to salinity changes between the Baltic and the Mediterranean experiments highlights the importance of the diverse species co-tolerances sensu Vinebrooke et al. (2004).

\section{Temperature and Salinity Changes Impact on Community Composition}

Our results show that heat shock lead to significantly different compositional communities which further shifted after salinity changes in both experimental sites supporting the first part of hypothesis 1 . Temperature increase is known to influence unicellular planktic communities and food web structure (Moran 
TABLE 2 | Log response ratio (LR) according to OTUs richness, evenness and $S_{\text {auto }} / S_{\text {het }}$ and $S_{\text {auto }} / S_{\text {grazers }}+$ parasites ratios in each experiment.

\begin{tabular}{|c|c|c|c|c|c|c|c|c|}
\hline & \multicolumn{2}{|c|}{ Response species richness } & \multicolumn{2}{|c|}{ Response evenness } & \multicolumn{2}{|c|}{ Response $\mathbf{S}_{\text {auto }} / \mathbf{S}_{\text {grazers + parasites }}$} & \multicolumn{2}{|c|}{ Response $\mathrm{S}_{\text {auto }} / \mathrm{S}_{\text {het }}$} \\
\hline & Baltic & Mediterranean & Baltic & Mediterranean & Baltic & Mediterranean & Baltic & Mediterranean \\
\hline$A_{f+}$ & -0.48 & -0.02 & -0.06 & -0.12 & -0.07 & 0.45 & -0.01 & 0.50 \\
\hline$A_{f-}$ & -0.29 & -0.30 & -0.44 & -0.69 & 0.13 & 0.15 & 0.03 & -0.05 \\
\hline $\mathrm{H}_{\mathrm{f}+}$ & -0.68 & -0.05 & -0.03 & -0.47 & 0.60 & 0.14 & 0.57 & 0.09 \\
\hline $\mathrm{H}_{\mathrm{f}-}$ & -0.23 & -0.08 & -0.37 & -0.58 & 1.16 & 0.07 & 0.80 & -0.02 \\
\hline
\end{tabular}

Values for the Mediterranean experiment are shaded.

et al., 2010; Lewandowska and Sommer, 2010; Moustaka-Gouni et al., 2016). In our experiments we found that the $H_{i}$ community in both experiments included more of smaller unicellular primary producers in comparison with the $\mathrm{A}_{\mathrm{i}}$ community as indicated by increased DNA-based OTUs of nanoplanktic Haptophyceae and picoplanktic Chlorophyceae together with decreased DNA-based OTUs of large diatoms and dinoflagellates. This shift toward smaller phytoplankters due to higher temperatures is seen as a manifestation of Bergmann's rule and has been found both at the global biogeographic scale and in individual experiments (reviewed by Sommer et al., 2016). While being less diverse in autotrophic OTUs, $\mathrm{H}_{\mathrm{i}}$ communities were richer in heterotrophic OTUs. Temperature comprises a major environmental factor controlling the metabolic rates of organisms (Brown et al., 2004) and several studies have indicated that heterotrophic processes are highly temperature dependent and are intensified by increased temperature (Lewandowska and Sommer, 2010; López-Urrutia et al., 2006). Indirect beneficial effects of the heat shock might have resulted from cell lysis of sensitive taxa and subsequent DOC-release (Wohlers et al., 2009) and, therefore, stimulated bacterial growth and provided food for grazers of bacteria (Moustaka-Gouni et al., 2016). These could be possible explanations for the compositional shifts toward unicellular heterotrophic flagellates at elevated temperatures. The very few shared DNA-based OTUs across the three salinity treatments were associated mainly with 4 taxonomic groups (Bacillariophyceae, Dinophyceae, Chlorophyceae, Fungi) and specifically the genera Skeletonema, Chaetoceros, Prorocentrum, Gyrodinium, Gymnodinium, Desmochloris, Kappamyces and several genera of the class Exobasidiomycetes. These genera are known for their euryhaline distribution in situ; several species of Chaetoceros have been recorded from estuaries (Terada and Ichimura, 1979) to hypersaline coastal lagoons (Gilabert, 2001). Skeletonema grows well between salinities of 10 and 35 psu (Balzano et al., 2011) and Prorocentrum between salinities of 20 to $40 \mathrm{psu}$ ( $\mathrm{Xu}$ et al., 2010). The aforementioned ranges included the salinity range of both experiments. Also, several Gyrodynium and Gymnodinium species have been characterized as euryhaline and formed red tides under different hydrographic conditions (Zingone and Enevoldsen, 2000; Nagasoe et al., 2006). The rarely studied green alga Desmochloris grows well both in freshwater and marine media (Darienko et al., 2009). Kappamyces and several genera of the class Exobasidiomycetes were recorded in several marine environments with different salinities across Europe (Richards et al., 2015). However, the high number of specific OTUs recorded in each of the three salinity levels demonstrated the strong salinity effects on biodiversity confirming that salinity can play a crucial role for differential survival of species (Logares et al., 2009). Besides, it is known that species even within the same taxonomic group exhibit different salinity tolerance (Brand, 1984; Park and Simpson, 2010). We have to add one caveat to the comparison with field distributions. Statements about tolerance ranges in our experiments are based on the standing genetic variation within small plankton samples, while tolerance ranges inferred from biogeographic distribution result from the global range of genetic variation of a taxon.

The decrease in OTU richness in $\mathrm{H}_{\mathrm{i}}$ in comparison with $A_{i}$ is in accordance with the second part of hypothesis 1 and parallels previous findings of negative effects of temperature increase on morpho-species richness in marine environments (Gruner et al., 2017) which has been suggested to result from faster species replacement under warmer conditions (Burgmer and Hillebrand, 2011) combined with the exclusion of invasions by new species in a closed experimental system. The reduced OTU richness after salinity changes in the Baltic experiment and under low salinity in the Mediterranean experiment is in agreement with the second part of hypothesis 1 and can be explained by cell physiology. This richness decrease was not observed under high salinity in the Mediterranean experiment for which we found a higher OTU richness both in A and $\mathrm{H}$ communities. Particularly, increased salinities positively affected the MAST and ciliophoran richness. The specific Mediterranean experiment site is influenced by riverine freshwater fluxes leading to a decreasing trend in salinity the last decade (Krestenitis et al., 2012). This recent salinity lowering in a generally high salinity marine environment of the Mediterranean might negatively affect the survival of Mediterranean marine protists while the experimentally increased salinities gave these organisms the opportunity to increase their biodiversity.

\section{Temperature and Salinity Changes Impact on Community Relative Abundance and Inferred Activity}

The high percentages of rare OTUs (>75\%) during the experiments match those of the majority of studies on marine protists (Stoeck et al., 2010; Logares et al., 2014). It has been hypothesized that rare marine microbes include ecologically redundant taxa that could increase in abundance following environmental changes and maintain continuous ecosystem functioning (Logares et al., 2015). In the Baltic experiment rare decomposers (Tolypocladium, Cladosporium, 
Thraustochytriaceae) became abundant after salinity changes and in the Mediterranean experiment picograzers rare at ambient salinity (Centroheliozoa, Caecitelus, Blepharisma) became abundant at high and low salinity. Our data showed a positive correlation between rRNA and rDNA relative abundance in both experiments in agreement with previous findings for marine protists (Logares et al., 2014). Contrary to marine bacteria that commonly present disproportionately low activity due to dormancy (Campbell et al., 2011), marine protist activity is usually positively correlated to their abundance (Logares et al., 2014).

The majority of the taxonomic and trophic groups in our experiments had increased or decreased rRNA:rDNA between $\mathrm{A}_{\mathrm{i}}$ and $\mathrm{H}_{\mathrm{i}}$ communities and after salinity changes in accordance with hypothesis 2 . However, using rRNA to distinguish active and non-active organisms has been criticized for its reliability (Blazewicz et al., 2013). The high variation of the overall range of rRNA:rDNA ratio for Amoebozoa, Apusozoa, Hacrobia and Fungi suggests that the activity of these taxonomic groups was affected more by increased temperature and salinity changes than the activity of Bacillariophyceae, Dinophyceae and MALVs which showed little changes of rRNA:rDNA across the treatments. The increased rRNA:rDNA ratios of Amoebozoa, Apuzosoa and MAST and at the same time of micrograzers and picograzers in $\mathrm{H}_{\mathrm{i}}$ community in comparison with $A_{i}$ can be attributed to more intensive heterotrophic processes at elevated temperatures. The remarkably increased rRNA:rDNA ratios for Haptophyceae and Telonemia under elevated salinity in the Baltic experiment (21.4 psu) may be coupled with their preference of high salinity Baltic Sea's microenvironments (from 18 to $22 \mathrm{psu}$ ) (Hu Y. et al., 2016) in conjunction with the availability of prey. Higher bacterial abundances and productivity have been also recorded in higher salinity Baltic Sea microenvironments in comparison with fresher microenvironments (Lindh et al., 2015). Finally, the increased rRNA:rDNA ratios in low salinity treatments for Fungi in the Mediterranean experiment (28.8 psu) can be explained by the accumulated dead matter observed under microscopy of samples (data not shown). Fungi have the role of decomposers in marine ecosystems (Richards et al., 2015) and their increased rRNA:rDNA ratios coincided with the reduced total OTU richness.

\section{Resistance}

Neither hypothesis 3 (decreased resistance after the heatshock) nor its opposite (increased resistance) were unequivocally supported by the calculated response according to the four selected metrics (OTUs richness, evenness, $S_{\text {auto }} / S_{\text {het }}$ and $\mathrm{S}_{\text {auto }} / \mathrm{S}_{\text {grazers }}+$ parasites ratios), except for the trophic state indicators in the Baltic experiment and to some extent by evenness in the Mediterranean experiment (true for salinity increase, false for salinity decrease). It is a longstanding assumption that biodiversity loss affects ecosystem function and decreases the resistance and the maintenance of ecosystem processes against environmental alterations (Loreau et al., 2001). The coexistence of many species in more biodiverse ecosystems provides a greater guarantee that some will back up when others fail after environmental disturbances (Wittebolle et al., 2009). In the Mediterranean experiment, we noticed a support of the above assumptions since the increased temperature-induced biodiversity loss in the $\mathrm{H}_{\mathrm{i}}$ community lead to lower resistance against salinity changes. According to the model of Vinebrooke et al. (2004) this would result from a negative correlation between heat and salinity tolerances of the OTUs. The genetically less biodiverse $\mathrm{H}_{\mathrm{i}}$ community lead salinity treatments to display greater change from initial community via greater species loss and consequently had lower resistance against increased/decreased salinity. Besides, it has been found that genetically less diverse communities have lower chances to contain taxa with complementary response traits and the ability for rapid compensatory growth after a disturbance which may decrease resistance (Shade et al., 2012). In our experiment, the nature of change (salinity increase vs. decrease), the choice of the response parameter and the geographic origin of the experimental community were at least as influential on resistance as diversity loss in response to the temperature pre-treatment. Both plankton communities originate from coastal ecosystems, where salinity changes are frequent. Thus, experimental communities might contain residuals of species adapted to higher or lower salinities than in situ ones, depending on the history of the local community. In the case of the heterotrophic OTUs, the autecological response to salinity change may be superseded by creation of additional niches by the death of non-resistant OTUs with subsequent detritus and DOC production, which fuels bacterial growth and thereby improves the feeding conditions for bacterivores.

\section{CONCLUSION}

In this study we examined the influence of biodiversity changes caused by an intermittent heat-shock on the sensitivity of plankton community to subsequent salinity changes. Our experiment provided evidence that the effect of the initial environmental stressor (heat wave) on plankton community resistance to the subsequent stressor (salinity changes) is contingent on the local species pool and the resultant patterns of species co-tolerance (sensu Vinebrooke et al., 2004). Identically designed mesocosm experiments were performed in the Baltic Sea where diatoms dominated in plankton DNA and RNA dataset and in the Mediterranean Sea where dinoflagellates were the dominant plankton OTUs. In the Baltic experiment, the less diverse heat shocked plankton communities showed a higher resistance to salinity changes in apparent contradiction to the assumption, that biodiversity should provide an insurance of ecosystem functions against environmental disturbances (Loreau et al., 2001). On the contrary, in the Mediterranean experiment the assumption that biodiversity acts as a buffer against environmental fluctuations was supported and the induced less biodiverse heated shocked community had lower resistance to salinity changes. The frequent strong environmental fluctuations (including salinity changes) in the Baltic Sea region most 
probably played a key role on the relatively increased resistance against the two stressors (heat-shock and salinity changes). On the other hand, the less exposed Mediterranean plankton community to environmental fluctuations had as a consequence the increased sensitivity, mainly in the heated community, against salinity alterations.

\section{AUTHOR CONTRIBUTIONS}

NS, US, and MM-G designed the experiment. NS and SG carried out the molecular, bioinformatics, and statistical analysis. NS carried out the experiment prepared the manuscript. NS, JL-B, US, and MM-G designed the research. NS, SG, JL-B, US, and $\mathrm{MM}-\mathrm{G}$ revised the manuscript.

\section{FUNDING}

This project was partially supported by the Alabama Greece Initiative, The University of Alabama. This research is implemented through IKY scholarships program and cofinanced by the European Union (European Social Fund ESF) and Greek national funds through the action entitled

\section{REFERENCES}

Altschul, S. F., Gish, W., Miller, W., Myers, E. W., and Lipman, D. J. (1990). Basic local alignment search tool. J. Mol. Biol. 215, 403-410. doi: 10.1016/S00222836(05)80360-2

Amann, R. I., Binder, B. J., Olson, R. J., Chisholm, S. W., Devereux, R., and Stahl, D. A. (1990). Combination of 16S rRNA-targeted oligo-nucleotide probes with flow cytometry for analyzing mixed microbial populations. Appl. Environ. Microbiol. 56, 1919-1925.

Andersson, A., Meier, H. E. M., and Ripszam, M. (2015). Projected climate change and Baltic Sea ecosystem management. Ambio 44(Suppl. 3), S345-S356. doi: 10.1007/s13280-015-0654-8

Baltar, F., Palovaara, J., Unrein, F., Catala, P., Hornak, K., Simek, K., et al. (2016). Marine bacterial community structure resilience to changes in protist predation under phytoplankton bloom conditions. ISME J. 10, 568-581. doi: 10.1038/ ismej.2015.135

Balzano, S., Sarno, D., and Kooistra, W. H. C. F. (2011). Effects of salinity on the growth rate and morphology of ten Skeletonema strains. J. Plankton Res. 33, 937-945. doi: 10.1093/plankt/fbq150

Behnke, A., Engel, M., Christen, R., Nebel, M., Klein, R. R., and Stoeck, T. (2011). Depicting more accurate pictures of protistan community complexity using pyrosequencing of hypervariable SSU rRNA gene regions. Environ. Microbiol. 13, 340-349. doi: 10.1111/j.1462-2920.2010.02332.x

Belkin, N., Rahav, E., Elifantz, H., Kress, N., and Berman-Frank, I. (2015). Enhanced salinities, as a proxy of seawater desalination discharges, impact coastal microbial communities of the eastern Mediterranean Sea. Environ. Microbiol. 17, 4105-4120. doi: 10.1111/1462-2920.12979

Bellard, C., Bertelsmeier, C., Leadley, P., Thuiller, W., and Courchamp, F. (2012). Impacts of climate change on the future of biodiversity. Ecol. Lett. 15, 365-377. doi: 10.1111/j.1461-0248.2011.01736.x

Benton, T. G., Solan, M., Travis, J. M. J., and Sait, S. M. (2007). Microcosm experiments can inform global ecological problems. Trends Ecol. Evol. 22, 516-521. doi: 10.1016/j.tree.2007.08.003

Bik, H. M., Porazinska, L. D., Creer, S., Caporaso, G., Knight, R., and Thomas, K. (2012). Sequencing our way towards understanding global eukaryotic biodiversity. Trends Ecol. Evol. 27, 233-243. doi: 10.1016/j.tree.2011. 11.010
"Scholarships program for postgraduates studies -2nd Study Cycle" in the framework of the Operational Program "Human Resources Development Program, Education and Lifelong Learning" of the National Strategic Reference Framework (NSRF) $2014-2020$.

\section{ACKNOWLEDGMENTS}

We are thankful to Prof. Konstantinos Ar. Kormas for providing the equipment to perform the nucleic acid extractions. The experiments are part of the BEN-Network (nonrandom biodiversity experiments network) initiated by A.M. Lewandowska (University of Helsinki, Tvärminne Zoological Station). Similar experiments using the same design are being conducted on other marine sites. We would like to thank two reviewers for helping improve our manuscript.

\section{SUPPLEMENTARY MATERIAL}

The Supplementary Material for this article can be found online at: https://www.frontiersin.org/articles/10.3389/fmicb. 2018.02444/full\#supplementary-material

Blazewicz, S. J., Barnard, R. L., Daly, R. A., and Firestone, M. K. (2013). Evaluating rRNA as an indicator of microbial activity in environmental communities: limitations and uses. ISME J. 7, 2061-2068. doi: 10.1038/ismej.2013.102

Bowen, J. L., Kearns, P. J., Holcomb, M., and Ward, B. B. (2013). Acidification alters the composition of ammonia-oxidizing microbial assemblages in marine mescosms. MEPS 492, 1-8. doi: 10.3354/meps10526

Brand, L. E. (1984). The salinity tolerance of forty-six marine phytoplankton isolates. Estuar. Coast Shelf Sci. 18, 543-556. doi: 10.1016/0272-7714(84) 90089-1

Brown, J. H., Gillooly, J. F., Allen, A. P., Savage, V. M., and West, G. B. (2004). Towards a metabolic theory of ecology. Ecology 85, 1771-1789. doi: 10.1890/ 03-9000

Burgmer, T., and Hillebrand, H. (2011). Temperature mean and variance alter phytoplankton biomass and biodiversity in a long-term microcosm experiment. Oikos 120, 922-933. doi: 10.1111/j.1600-0706.2010.19301.x

Campbell, B. J., Yu, L., Heidelberg, J. F., and Kirchman, D. L. (2011). Activity of abundant and rare bacteria in a coastal ocean. Proc. Natl. Acad. Sci. U.S.A. 108, 12776-12781. doi: 10.1073/pnas.1101405108

Chao, A., Chazdon, R. L., Colwell, R. K., and Shen, T.-J. (2005). A new statistical approach for assessing similarity of species composition with incidence and abundance data. Ecol. Lett. 8, 148-159. doi: 10.1111/j.1461-0248.2004. 00707.x

Christaki, U., Kormas, K. A., Genitsaris, S., Georges, C., Sime-Ngado, T., Viscogliosi, E., et al. (2014). Winter-summer succession of unicellular eukaryotes in a meso-eutrophic coastal system. Microb. Ecol. 67, 13-23. doi: 10.1007/s00248-013-0290-4

Countway, P. D., Gast, R. J., Savai, P., and Caron, D. A. (2005). Protistan diversity estimates based on 18S rDNA from seawater incubations in the western north Atlantic. J. Eukaryot. Microbiol. 52, 95-106. doi: 10.1111/j.1550-7408.2005. 05202006.x

Darienko, T., Friedl, T., and Pröschold, T. (2009). Desmochloris mollenhaueri a new terrestrial ulvophycean alga from South-west African soils. (Molecular phylogeny and systematics of terrestrial Ulvophyceae I). Algol. Stud. 129, 25-40. doi: 10.1127/1864-1318/2009/0129-0025

de Vargas, C., Audic, S., Henry, N., Decelle, J., Mahe, F., Logares, R., et al. (2015). Eukaryotic plankton diversity in the sunlit ocean. Science 348:1261605. doi: 10.1126/science. 1261605 
Dowd, S. E., Sun, Y., Secor, P. R., Rhoads, D. D., Wolcott, B. M., James, G. A., et al. (2008). Survey of bacterial diversity in chronic wounds using pyrosequencing, DGGE, and full ribosome shotgun sequencing. BMC Microbiol. 8:43. doi: 10.1186/1471-2180-8-43

Edgar, R. C. (2010). Search and clustering orders of magnitude faster than BLAST. BMC 26, 2460-2461. doi: 10.1093/bioinformatics/btq461

Genitsaris, S., Monchy, S., Viscogliosi, E., Sime-Ngando, T., Ferreira, S., and Christaki, U. (2015). Seasonal variations of marine protist community structure based on taxon-specific traits using the eastern English Channel as a model coastal system. FEMS Microbiol. Ecol. 91:fiv034. doi: 10.1093/femsec/fiv034

Gilabert, J. (2001). Seasonal plankton dynamics in a Mediterranean hypersaline coastal lagoon: the Mar Menor. J. Plankton Res. 23, 207-218. doi: 10.1093/ plankt/23.2.207

Gruner, D. S., Bracken, M. E. S., Berger, S. A., Eriksson, B. K., Gamfeldt, L., Matthiesen, B., et al. (2017). Effects of experimental warming on biodiversity depend on ecosystem type and local species composition. Oikos 126, 8-17. doi: $10.1111 /$ oik.03688

Guillou, L., Bachar, D., Audic, S., Bass, D., Berney, C., Lucie, B., et al. (2013). The Protist Ribosomal Reference database (PR2): a catalog of unicellular eukaryote small sub-unit rRNA sequences with curated taxonomy. Nucleic Acid Res. 41, 597-604. doi: 10.1093/nar/gks1160

Guo, C., Xia, X., Pitta, P., Herut, B., Rahal, E., Berman-Frank, I., et al. (2016). Shifts in microbial community structure and activity in the ultra-oligotrophic eastern Mediterranean sea driven by the deposition of Saharan dust and European aerosols. Front. Mar. Sci. 3:170.

Harley, C. D., Hughes, A. R., Hultgren, K. M., Miner, B. G., Sorte, C. J. B., and Thornber, C. S. (2006). The impacts of climate change in coastal marine systems. Ecol. Lett. 9, 228-241. doi: 10.1111/j.1461-0248.2005.00871.x

Hu, S. K., Campbell, V., Connell, P., Gellene, A. G., Liu, Z., Terrado, R., et al. (2016). Protistan diversity and activity inferred from RNA and DNA at a coastal ocean site in the eastern North Pacific. FEMS Microbiol. Ecol. 92:fiw050. doi: 10.1093/femsec/fiw050

Hu, Y., Karlson, B., Charvet, S., and Andersson, A. F. (2016). Diversity of Picoto Mesoplankton along the $2000 \mathrm{~km}$ salinity gradient of the Baltic Sea. Front. Microbiol. 7:679. doi: 10.3389/fmicb.2016.00679

Intergovernmental Panel on Climate Change [IPCC] (2014). Climate change 2014: Impacts, Adaptation and Vulnerability. IPCC Working Group II Contribution to the 5th Assessment report of the International Panel on Climate Change. Cambridge: Cambridge University Press. doi: 10.1017/CBO9781107415416

Kaur-Kahlon, G., Kumar, S., Rehnstam-Holm, A. S., Rai, A., Bhavya, P. S., Edler, L., et al. (2016). Response of a coastal tropical pelagic microbial community to changing salinity and temperature. Aquat. Microb. Ecol. 77, 37-50. doi: 10.3354/ ame 01785

Krestenitis, Y. N., Kombiadou, K. D., and Androulidakis, Y. S. (2012). Interannual variability of the physical characteristics of North Thermaikos Gulf (NW Aegean Sea). J. Mar. Syst. 96-97, 32-151. doi: 10.1016/j.jmarsys.2012.02.017

Kunin, V., Engelbrektson, A., Ochman, H., and Hugenholtz, P. (2010). Wrinkles in the rare biosphere: pyrosequencing errors can lead to artificial inflation of diversity estimates. Environ. Microbiol. 12, 118-123. doi: 10.1111/j.1462-2920. 2009.02051.x

Lebaron, P., Servais, P., Troussellier, M., Courties, C., Courties, C., Vives-Rego, J., et al. (1999). Changes in bacterial community structure in seawater mesocosms differing in their nutrient status. Aquat. Microb. Ecol. 19, 255-267. doi: 10.3354/ ame 019255

Lewandowska, A. M., and Sommer, U. (2010). Climate change and the spring bloom: a mesocosm study on the influence of light and temperature on phytoplankton and mesozooplankton. MEPS 405, 101-111. doi: 10.3354/ meps08520

Lindh, M. V., Figueroa, D., Sjöstedt, J., Baltar, F., Lundin, D., Andersson, A., et al. (2015). Transplant experiments uncover Baltic Sea basin-specific responses in bacterioplankton community composition and metabolic activities. Front. Microbiol. 6:223. doi: 10.3389/fmicb.2015.00223

Logares, R., Audic, S., Bass, D., Bittner, L., Boutte, C., Christen, R., et al. (2014). Patterns of rare and abundant marine microbial eukaryotes. Curr. Biol. 24, 813-821. doi: 10.1016/j.cub.2014.02.050

Logares, R., Bråte, J., Bertilsson, S., Clasen, J. L., Shalchian-Tabrizi, K., and Rengefors, K. (2009). Infrequent marine-freshwater transitions in the microbial world. Trends Microbiol. 17, 414-422. doi: 10.1016/j.tim.2009.05.010
Logares, R., Mangot, J. F., and Massana, R. (2015). Rarity in aquatic microbes: placing protists on the map. Res. Microbiol. 166, 831-841. doi: 10.1016/j.resmic. 2015.09.009

Lopez-Garcia, P., Philippe, H., Gail, F., and Moreira, D. (2003). Autochthonous eukaryotic diversity in hydrothermal sediment and experimental microcolonizers at the Mid-Atlantic Ridge. Proc. Natl. Acad. Sci. U.S.A. 100, 697-702. doi: 10.1073/pnas.0235779100

López-Urrutia, A., San Martin, E., Harris, R. P., and Irigoien, X. (2006). Scaling the metabolic balance of the oceans. Proc. Natl. Acad. Sci. U.S.A. 103, 8739-8744. doi: 10.1073/pnas.0601137103

Loreau, M., Naeem, S., Inchausti, P., Bengtsson, J., Grime, J. P., Hector, A., et al. (2001). Biodiversity and ecosystem functioning: current knowledge and future challenges. Science 294, 804-808. doi: 10.1126/science.1064088

Mangot, J. F., Domaizon, I., Taib, N., Marouni, N., Duffaud, E., Bronner, G., et al. (2013). Short-term dynamics of diversity patterns: evidence of continual reassembly within lacustrine small eukaryotes. Environ. Microbiol. 15, 1745-1758. doi: 10.1111/1462-2920.12065

Massana, R., Gobet, A., Audic, S., Bass, D., Bittner, L., Boutte, C., et al. (2015). Marine protist diversity in European coastal waters and sediments as revealed by high-throughput sequencing. Environ. Microbiol. 17, 4035-4049. doi: 10. 1111/1462-2920.12955

Medinger, R., Nolte, V., Pandey, R. V., Jost, S., Ottenwalder, B., Schlotterer, C., et al. (2010). Diversity in a hidden world: potential and limitation of next-generation sequencing for surveys of molecular diversity of eukaryotic microorganisms. Mol. Ecol. 19, 32-40. doi: 10.1111/j.1365-294X.2009.04478.x

Meier, M. E. H., Kjellström, E., and Graham, P. (2006). Estimating uncertainties of projected Baltic Sea salinity in the late 21st century. Geophys. Res. Lett. 33:L15707. doi: 10.1029/2006GL026488

Mihalatou, H. M., and Moustaka-Gouni, M. (2002). Pico-, Nano-, microplankton abundance and primary productivity in a Eutrophic coastal area of the Aegean sea, Mediterranean. Int. Rev. Hydrobiol. 87, 439-456. doi: 10.1002/15222632(200207)87:4<439::AID-IROH439>3.0.CO;2-3

Moran, X. A. G., Lopez-Urrutia, Á, Calvo-Diaz, A., and William, K. W. L. (2010). Increasing importance of small phytoplankton in a warmer ocean. Glob. Change Biol. 16, 1137-1144. doi: 10.1111/j.1365-2486.2009.01960.x

Moreira, D., and López-García, P. (2014). The rise and fall of Picobiliphytes: how assumed autotrophs turned out to be heterotrophs. BioEssays 36, 468-474. doi: 10.1002/bies.201300176

Moustaka-Gouni, M., Kormas, K. A., Scotti, M., Vardaka, E., and Sommer, U. (2016). Warming and Acidification Effects on Planktonic Heterotrophic Picoand Nanoflagellates in a Mesocosm Experiment. Protist 167, 389-410. doi: 10.1016/j.protis.2016.06.004

Muscarella, M. E., Bird, K. C., Larsen, M. L., Placella, S. A., and Lennon, J. T. (2014). Phosphorus resource heterogeneity in microbial food webs. Aquat. Microb. Ecol. 73, 259-272. doi: 10.3354/ame01722

Nagasoe, S., Kim, D., Shimasaki, Y., Oshima, Y., Yamaguchi, M., and Honjo, T. (2006). Effects of temperature, salinity and irradiance on the growth of the red tide dinoflagellate Gyrodinium instriatum Freudenthal et Lee. Harmful Algae 5, 20-25. doi: 10.1016/j.hal.2005.06.001

Newbold, L. K., Oliver, A. E., Booth, T., Tiwari, B., Desantis, T., Maguire, M., et al. (2012). The response of marine picoplankton to ocean acidification. Environ. Microbiol. 14, 2293-2307. doi: 10.1111/j.1462-2920.2012.02762.x

Nikolaides, G., and Moustaka-Gouni, M. (1990). The structure and dynamics of phytoplankton assemblages from the inner part of the Thermaikos Gulf, Greece. I. Phytoplankton composition and biomass from May 1988 to April 1989. Helgol. Wiss Meeresunters 44, 487-501. doi: 10.1007/BF02365482

Park, J. S., and Simpson, A. G. (2010). Characterization of halotolerant Bicosoecida and Placididea (Stramenopila) that are distinct from marine forms, and the phylogenetic pattern of salinity preference in heterotrophic stramenopiles. Environ. Microbiol. 12, 1173-1184. doi: 10.1111/j.1462-2920.2010.02158.x

Poulsen, L. K., Ballard, G., and Stahl, D. A. (1993). Use of rRNA fluorescence in situ hybridization for measuring the activity of single cells in young and established biofilms. Appl. Environ. Microb. 59, 1354-1360.

Quast, C., Pruesse, E., Yilmaz, P., Gerken, J., Schweer, T., Yarza, P., et al. (2013). The SILVA ribosomal RNA gene database project: improved data processing and web-based tools. Nucleic Acids Res. 41, D590-D596. doi: 10.1093/nar/gks1219

Richards, T. A., Leonard, G., Mahé, F., del Campo, J., Romac, S., Jones, M. D. M., et al. (2015). Molecular diversity and distribution of marine fungi across 130 
European environmental samples. Proc. R. Soc. B 282:20152243. doi: 10.1098/ rspb.2015.2243

Schloss, P. D., Gevers, D., and Westcott, S. L. (2011). Reducing the effects of PCR amplification and sequencing artifacts on $16 \mathrm{~S}$ rRNA-based studies. PLoS One 6:e27310. doi: 10.1371/journal.pone.0027310

Schloss, P. D., Westcott, S. L., Ryabin, T., Hall, J. R., Hartmann, M., Hollister, E. B., et al. (2009). Introducing mothur: open-source, platform-independent, community-supported software for describing and comparing microbial communities. Appl. Environ. Microbiol. 75, 7537-7541. doi: 10.1128/AEM. 01541-09

Shade, A., Peter, H., Allison, S., Baho, D. L., Berga, M., Bürgmann, H., et al. (2012). Fundamentals of microbial community resistance and resilience. Front. Microbiol. 3:417. doi: 10.3389/fmicb.2012.00417

Simboura, N., Pavlidou, A., Bald, J., Tsapakis, M., Pagou, K., Zeri, C. H., et al. (2016). Response of ecological indices to nutrient and chemical contaminant stress factors in Eastern Mediterranean coastal waters. Ecol. Indic. 70, 89-105. doi: 10.1016/j.ecolind.2016.05.018

Skovgaard, A. (2014). Dirty tricks in the plankton: diversity and role of marine parasitic protists. Acta Protozool. 53, 51-62.

Sommer, U., Peter, K. H., Genitsaris, S., and Moustaka-Gouni, M. (2016). Do marine phytoplankton follow Bergmann's rule sensu lato? Biol. Rev. 92, 1011-1026. doi: 10.1111/brv.12266

Stoeck, T., Bass, D., Nebel, M., Christen, R., Jones, M. D., Breiner, H. W., et al. (2010). Multiple marker parallel tag environmental DNA sequencing reveals a highly complex eukaryotic community in marine anoxic water. Mol. Ecol. 19, 21-31. doi: 10.1111/j.1365-294X.2009.04480.x

Terada, T., and Ichimura, S. (1979). Environmental properties and the distribution of phytoplankton biomass and photosynthesis in a small eutrophic estuary of Shimoda Bay. La Mer 4, 137-144.

Utermöhl, H. (1958). Zur Vervollkommnung der quantitativen PhytoplanktonMethodik. Mitt Int Ver Theor Angew Limnol 9, 263-272.

van der Zaan, B., Smidt, H., de Vos, W. M., Rijnaarts, H., and Gerritse, J. (2010). Stability of the total and functional microbial communities in river sediment mesocosms exposed to anthropogenic disturbances. FEMS Microbiol. Ecol. 74, 72-82. doi: 10.1111/j.1574-6941.2010.00931.x

Vinebrooke, R. D., Cottingham, K. L., Norberg, J., Scheffer, M., Dodson, S. I., Maberly, S. C., et al. (2004). Impacts of multiple stressors on biodiversity and ecosystem functioning: the role of species co-tolerance. Oikos 104, 451-457. doi: 10.1111/j.0030-1299.2004.13255.x

Wasmund, N., Göbel, J., and Bodungen, V. B. (2008). 100-years-changes in the phytoplankton community of Kiel Bight (Baltic Sea). J. Mar. Syst. 73, 300-322. doi: 10.1016/j.jmarsys.2006.09.009

Wilsey, B. J., and Potvin, C. (2000). Biodiversity and ecosystems functioning: importance of species evenness in an old field. Ecology 81, 887-892. doi: 10.1890/0012-9658(2000)081[0887:BAEFIO]2.0.CO;2

Wittebolle, L., Marzorati, M., Clement, L., Balloi, A., Daffonchio, D., Heylen, K., et al. (2009). Initial community evenness favours functionality under selective stress. Nature 458, 623-626. doi: 10.1038/nature07840

Wohlers, J., Engel, A., Zöllner, E., Breithaupt, P., Jurgens, K., Hoppe, H. G., et al. (2009). Changes in biogenic carbon flow in response to sea surface warming. Proc. Natl. Acad. Sci. U.S.A. 106, 7067-7072. doi: 10.1073/pnas.0812743106

Xu, N., Duan, S., Li, A., Zhang, C., Cai, Z., and Hu, Z. (2010). Effects of temperature, salinity and irradiance on the growth of the harmful dinoflagellate Prorocentrum donghaiense Lu. Harmful Algae 9, 13-17. doi: 10.1016/j.hal.2009. 06.002

Yvon-Durocher, G., Allen, A. P., Cellamare, M., Dossena, M., Gaston, K. J., Leitao, M., et al. (2015). Five Years of experimental warming increases the biodiversity and productivity of phytoplankton. PLoS Biol. 13:e1002324. doi: 10.1371/journal.pbio.1002324

Zingone, A., and Enevoldsen, H. O. (2000). The diversity of harmful algal blooms: a challenge for science and management. Ocean Coast. Manage. 43, 725-748. doi: 10.1016/S0964-5691(00)00056-9

Conflict of Interest Statement: The authors declare that the research was conducted in the absence of any commercial or financial relationships that could be construed as a potential conflict of interest.

Copyright (c) 2018 Stefanidou, Genitsaris, Lopez-Bautista, Sommer and MoustakaGouni. This is an open-access article distributed under the terms of the Creative Commons Attribution License (CC BY). The use, distribution or reproduction in other forums is permitted, provided the original author(s) and the copyright owner(s) are credited and that the original publication in this journal is cited, in accordance with accepted academic practice. No use, distribution or reproduction is permitted which does not comply with these terms. 